\title{
Increased mortality associated with meticillin- resistant Staphylococcus aureus (MRSA) infection in the Intensive Care Unit: results from the EPIC II study
}

Håkan Hanberger, Sten Walther, Marc Leone, Philip S Barie, Jordi Rello, Jeffrey Lipman, John C Marshall, Antonio Anzueto, Yasser Sakr, Peter Pickkers, Peter Felleiter, Milo Engoren and Jean-Louis Vincent

\section{Linköping University Post Print}

N.B.: When citing this work, cite the original article.

Original Publication:

Håkan Hanberger, Sten Walther, Marc Leone, Philip S Barie, Jordi Rello, Jeffrey Lipman, John C Marshall, Antonio Anzueto, Yasser Sakr, Peter Pickkers, Peter Felleiter, Milo Engoren and Jean-Louis Vincent, Increased mortality associated with meticillin-resistant Staphylococcus aureus (MRSA) infection in the Intensive Care Unit: results from the EPIC II study, 2011, International Journal of Antimicrobial Agents, (38), 4, 331-335.

http://dx.doi.org/10.1016/j.ijantimicag.2011.05.013

Copyright: Elsevier

http://www.elsevier.com/

Postprint available at: Linköping University Electronic Press

http://urn.kb.se/resolve?urn=urn:nbn:se:liu:diva-70731 


\section{Increased mortality associated with meticillin-resistant}

Staphylococcus aureus (MRSA) infection in the Intensive Care Unit: results from the EPIC II study

Håkan Hanberger ${ }^{a}$, Sten Walther ${ }^{b}$, Marc Leone ${ }^{c}$, Philip S. Barie ${ }^{d}$, Jordi Rello ${ }^{e}$, Jeffrey Lipman ${ }^{f}$, John C. Marshall ${ }^{g}$, Antonio Anzueto ${ }^{\text {h}}$, Yasser Sakr ${ }^{i}$, Peter Pickkers ${ }^{j}$, Peter Felleiter ${ }^{k}$, Milo Engoren ', Jean-Louis Vincent ${ }^{\mathrm{m}, *}$; EPIC II Group of Investigators

${ }^{a}$ Division of Infectious Diseases, Institution of Clinical and Experimental Medicine, Faculty of Health Sciences, Linköping University, Sweden

${ }^{\mathrm{b}}$ Division of Cardiovascular Medicine, Department of Medical and Health Sciences, Linköping University, Sweden

${ }^{c}$ Department of Anesthesiology and Intensive Care Medicine, Nord Hospital, Marseille, France

${ }^{d}$ Department of Surgery, Weill Cornell Medical College, 1300 York Ave., P713A, New York, NY 10021, USA

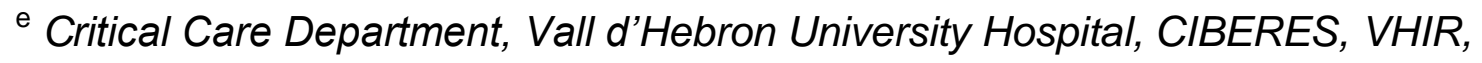
Universitat Autónoma de Barcelona, Spain

${ }^{\dagger}$ Department of Intensive Care Medicine, Royal Brisbane and Women's Hospital and Burns Trauma Critical Care Research Centre, University of Queensland, Queensland, Australia

${ }^{9}$ Department of Surgery, University of Toronto, St Michael's Hospital, Toronto, Ontario 
${ }^{\mathrm{h}}$ Department of Pulmonary/Critical Care, University of Texas Health Science Center, San Antonio, Texas, USA

' Department of Anesthesiology and Intensive Care, Friedrich-Schiller University, Jena, Germany

${ }^{j}$ Department of Intensive Care Medicine, Radboud University Nijmegen Medical Centre, Nijmegen, The Netherlands

${ }^{k}$ Intensive Care Medicine, Swiss Paraplegic Centre, 6207 Nottwil, Switzerland ' Department of Anesthesiology, Mercy St Vincent Medical Center, Toledo, OH, USA

${ }^{m}$ Department of Intensive Care, Erasme Hospital, Université libre de Bruxelles, Route de Lennik 808, B-1070 Brussels, Belgium

\section{ARTICLE INFO}

Article history:

Received 12 May 2011

Accepted 24 May 2011

Keywords:

Antimicrobial resistance

Sepsis

Mortality

Critically ill

* Corresponding author. Tel.: +32 2555 3380; fax: +32 25554555 .

E-mail address: jlvincen@ulb.ac.be (J.-L. Vincent). 


\section{ABSTRACT}

Controversy continues regarding whether the presence of meticillin resistance increases mortality risk in Staphylococcus aureus infections. In this study, we assessed the role of meticillin resistance in survival of patients with $S$. aureus infection included in the EPIC II point-prevalence study of infection in critically ill patients performed on 8 May 2007. Demographic, physiological, bacteriological and therapeutic data were collected for 13796 adult patients in 1265 participating Intensive Care Units (ICUs) from 75 countries on the study day. ICU and hospital outcomes were recorded. Characteristics of patients with meticillin-sensitive $S$. aureus (MSSA) and meticillin-resistant $S$. aureus (MRSA) infections were compared. Co-morbidities, age, Simplified Acute Physiology Score (SAPS) II, site of infection, geographical region and MRSA/MSSA were entered into a multivariate model, and adjusted odds ratios (ORs) [95\% confidence interval $(\mathrm{Cl})]$ for ICU and hospital mortality rates were calculated. On the study day, $7087(51 \%)$ of the 13796 patients were classified as infected. There were 494 patients with MRSA infections and 505 patients with MSSA infections. There were no significant differences between the two groups in use of mechanical ventilation or haemofiltration/haemodialysis. Cancer and chronic renal failure were more prevalent in MRSA than in MSSA patients. ICU mortality rates were $29.1 \%$ and $20.5 \%$, respectively $(P<0.01)$ and corresponding hospital mortality rates were $36.4 \%$ and $27.0 \%(P<0.01)$. Multivariate analysis of hospital mortality for MRSA infection showed an adjusted OR of $1.46(95 \% \mathrm{Cl} 1.03-$ 2.06) $(P=0.03)$. In ICU patients, MRSA infection is therefore independently associated with an almost 50\% higher likelihood of hospital death compared with MSSA infection. 


\section{Introduction}

Staphylococcus aureus is a common cause of infection in intensive care patients and in many cases it is resistant to meticillin [1]. However, whether meticillin resistance increases mortality in patients with $S$. aureus infection remains controversial. Some investigations and meta-analyses have reported that meticillin resistance does increase the mortality risk [2-7], whereas others have been unable to demonstrate any difference in mortality between meticillin-resistant $S$. aureus (MRSA) and meticillin-sensitive S. aureus (MSSA) infections [8-15]. The conflicting results may be explained by differences in setting, sample size, case mix, strain virulence, minimum inhibitory concentration (MIC), antibiotic choice, antibiotic dosage and timing of appropriate antimicrobial therapy.

The 1-day point-prevalence study Extended Prevalence of Infection in the ICU (EPIC II) showed that, on the day of the study, 7087 (51\%) of 13796 patients were classified as infected, and $70 \%$ of these had positive cultures; $47 \%$ of the positive isolates were Gram-positive [16]. The five most commonly isolated organisms were S. aureus (20.5\%), Pseudomonas spp. (19.9\%), Candida spp. (17.0\%), Escherichia coli (16\%) and Klebsiella spp. (12.7\%); $49.4 \%$ of the S. aureus isolates were MRSA [16].

The purpose of the present study was to compare the characteristics of patients with MRSA and MSSA infections in the EPIC II study cohort and to assess the independent role of meticillin resistance in mortality in these patients. 


\section{Methods}

The EPIC II 1-day point-prevalence study of infection in critically ill patients was performed on 8 May 2007 [16]. Demographic, physiological, bacteriological and therapeutic data were collected from 13796 adult (>18 years) patients in 1265 participating Intensive Care Units (ICUs) (Supplementary Appendix 1) from 75 countries on the study day, as described previously [16]. Simplified Acute Physiology Score (SAPS) II and Sequential Organ Failure Assessment (SOFA) scores were calculated for the study day. Local ethical committee approval at each participating centre was expedited or waived owing to the purely observational nature of the study. Infection was defined according to the criteria of the International Sepsis Forum [17] and was classified by the attending physician. Microbiological analyses, including meticillin susceptibility testing, were performed locally.

Patients who had undergone surgery in the 4 weeks preceding admission were considered surgical admissions. Elective surgery was defined as surgery scheduled $>24 \mathrm{~h}$ in advance, and emergency surgery as that scheduled within $24 \mathrm{~h}$. Trauma admissions were defined as ICU admissions directly related to, or occurring as a complication of, a traumatic event in the 30 days preceding admission. All other admissions were considered medical. We did not differentiate among communityacquired, healthcare-acquired or ICU-acquired infections. Participating ICUs were asked to provide patient follow-up until hospital discharge or for 60 days (until 9 July 2007), and ICU and hospital outcomes were recorded. 
For the purposes of this study, just those patients who were assessed by their physician as having clinical infection and had positive $S$. aureus isolates were selected.

\subsection{Statistics}

Statistical analyses were performed using PASW Statistics 18 for windows (SPSS Inc., Chicago, IL). The Kolmogorov-Smirnov test was used, and histograms and normal quantile plots were examined to verify whether there were significant deviations from the normality assumption of continuous variables. Non-parametric tests of comparison were used for variables evaluated as non-normally distributed. Difference testing between groups was performed using Student's t-test, MannWhitney test, $\chi^{2}$ test or Fisher's exact test as appropriate. Multivariate logistic regression analyses with ICU or hospital mortality as the dependent variables were performed to determine risk factors for mortality in patients with $S$. aureus infection. Odds ratios (ORs) were adjusted for hospital- and organisational-related factors, including type of ICU (closed versus open, community versus university, surgical versus medical), number of ICU beds, number of nurses, number of physiotherapists, presence of 24-h ICU physician coverage, length of ICU stay prior to study day, adequacy of antibiotic therapy and geographical region). Collinearity between variables was excluded prior to modelling. Interactions between explanatory variables were also checked. Data are presented as median [interquartile range (IQR)] or number (\%) as appropriate. All tests were two-tailed and a $P$-value of $<0.05$ was considered statistically significant. 


\section{Results}

\subsection{Characteristics of patients with MRSA versus MSSA infections}

There was considerable variation in the percentages of patients with MRSA/MSSA according to geographical region (Fig. 1). The characteristics of patients with MRSA $(n=494)$ and MSSA $(n=505)$ infections are shown in Table 1 . There were no differences in SAPS II and SOFA scores on admission between groups. Patients with MRSA were slightly older and had longer ICU stays prior to the study date than those with MSSA [median (IQR) 10 days (3-22 days) vs. 7 days (3-14 days); $P<0.001$ ]. Patients with MSSA were more likely to be admitted from the emergency department, whereas patients with MRSA were more likely to be admitted from a hospital ward. Neurological disease was a more common reason for admission in patients with MSSA infection than in those with MRSA, whereas respiratory, digestive tract and liver disease were more frequent reasons in MRSA-infected patients. Cancer and chronic renal failure were more prevalent in MRSA than in MSSA patients. There were no differences in use of mechanical ventilation, haemofiltration or haemodialysis between the groups.

\subsection{Site of infection and concomitant infections}

The most common site of infection was the respiratory system, followed by the bloodstream and renal/urinary tract (Table 2). MRSA isolates were more common than MSSA isolates in patients with abdominal infections (16.6\% vs. $7.7 \% ; P<0.001)$ and renal/urinary tract infections $(16.6 \%$ vs. $11.5 \% ; P=0.02)$ and were less common in patients with central nervous system infections $(1.8 \%$ vs. $5.1 \% ; P<0.01)$. 
Table 1

Characteristics of patients with meticillin-resistant Staphylococcus aureus (MRSA) and meticillin-sensitive $S$. aureus (MSSA) infections in the Extended Prevalence of Infection in the ICU (EPIC II) study

Characteristic $\quad \operatorname{MRSA}(n=494) \quad \operatorname{MSSA}(n=505) \quad P$-value

\begin{tabular}{|c|c|c|c|}
\hline Age (years) [median (IQR)] & $63(50-74)$ & $62(44-72)$ & 0.01 \\
\hline Sex male $[n(\%)]$ & $322(65.2)$ & $343(67.9)$ & 0.38 \\
\hline SAPS II [median (IQR)] & $37(27-49)$ & 37 (27-49) & 0.87 \\
\hline SOFA [median (IQR)] & $6(4-10)$ & $7(4-10)$ & 0.64 \\
\hline Days in ICU prior to study date [median (IQR)] & $10(3-22)$ & $7(3-14)$ & $<0.001$ \\
\hline \multicolumn{3}{|c|}{ Type of admission $[n(\%)]^{\mathrm{a}}$} & 0.08 \\
\hline Surgical: elective & $70(14.2)$ & $60(11.9)$ & \\
\hline Medical & $151(30.6)$ & $148(29.4)$ & \\
\hline Surgical: emergency & $226(45.8)$ & $223(44.2)$ & \\
\hline Trauma & $46(9.3)$ & $73(14.5)$ & \\
\hline \multicolumn{3}{|l|}{ Admission source $[n(\%)]^{b}$} & $<0.01$ \\
\hline Operating room/recovery & $88(17.8)$ & $87(17.3)$ & \\
\hline Emergency department/ambulance & $116(23.5)$ & $168(33.5)$ & \\
\hline Hospital ward & $181(36.7)$ & $130(25.9)$ & \\
\hline Other hospital & $97(19.7)$ & $101(20.1)$ & \\
\hline Other & $11(2.2)$ & $16(3.2)$ & \\
\hline \multicolumn{3}{|l|}{ Reason for admission $[n(\%)]$} & $<0.001$ \\
\hline Surveillance/monitoring & $49(9.9)$ & $37(7.3)$ & \\
\hline Neurological & $55(11.1)$ & $118(23.4)$ & \\
\hline Respiratory & $165(33.4)$ & $122(24.2)$ & \\
\hline Cardiovascular & $101(20.4)$ & $114(22.6)$ & \\
\hline Renal & $12(2.4)$ & $10(2.0)$ & \\
\hline Digestive/liver & $52(10.5)$ & $30(5.9)$ & \\
\hline Trauma & $48(9.7)$ & $63(12.5)$ & \\
\hline Other & $12(2.4)$ & $11(2.2)$ & \\
\hline \multicolumn{4}{|l|}{ Co-morbidity $[n(\%)]$} \\
\hline COPD & $97(19.6)$ & $91(18.0)$ & 0.51 \\
\hline Cancer & $80(16.2)$ & $53(10.5)$ & $<0.01$ \\
\hline Haematological cancer & $11(2.2)$ & $11(2.2)$ & 0.96 \\
\hline Insulin-dependent diabetes mellitus & $72(14.6)$ & $66(13.1)$ & 0.49 \\
\hline Heart failure (NYHA III-IV) & $68(13.8)$ & $53(10.5)$ & 0.11 \\
\hline Chronic renal failure & $71(14.4)$ & $51(10.1)$ & 0.04 \\
\hline HIV & $3(0.6)$ & $2(0.4)$ & 0.64 \\
\hline Cirrhosis & $29(5.9)$ & $20(4.0)$ & 0.16 \\
\hline Immunosuppression & $22(4.5)$ & $20(4.0)$ & 0.34 \\
\hline \multicolumn{3}{|l|}{ Number of co-morbidities [ $n(\%)]$} & $<0.01$ \\
\hline None & $194(39.3)$ & $249(49.3)$ & \\
\hline 1 & $158(32.0)$ & $160(31.7)$ & \\
\hline 2 & $94(19.0)$ & $60(11.9)$ & \\
\hline 3 & $36(7.3)$ & $28(5.5)$ & \\
\hline$\geq 4$ & $12(2.4)$ & $8(1.6)$ & \\
\hline Mechanical ventilation $[n(\%)]^{c}$ & $341(69.0)$ & $353(70.2)$ & 0.69 \\
\hline Haemofiltration/haemodialysis [ $n(\%)]$ & $67(13.6)$ & $61(12.1)$ & 0.5 \\
\hline Antibiotic treatment $[n(\%)]$ & $475(96.2)$ & $485(96.0)$ & 0.79 \\
\hline \multicolumn{4}{|c|}{$\begin{array}{l}\text { IQR, interquartile range; SAPS II, Simplified Acute Physiology Score II; SOFA, Sequential Organ } \\
\text { Failure Assessment; ICU, Intensive Care Unit; COPD, chronic obstructive pulmonary disease; NYHA } \\
\text { III-IV, New York Heart Association class III-IV; HIV, human immunodeficiency virus. } \\
\text { a data missing for } 1 \text { patient in each group } \\
\text { b data missing for } 1 \text { patient in MRSA group and } 3 \text { patients in MSSA group } \\
\text { c data missing for } 2 \text { patients in the MSSA group }\end{array}$} \\
\hline
\end{tabular}


Table 2. Site of infection in patients with meticillin-resistant Staphylococcus aureus (MRSA) and meticillin-sensitive $S$. aureus (MSSA) infections. ${ }^{\text {a }}$

\begin{tabular}{|l|l|l|l|}
\hline Site of infection & MRSA [n (\%)] & MSSA [n (\%)] & $\boldsymbol{P}$-value \\
\hline Respiratory tract & $364(73.7)$ & $346(68.5)$ & 0.07 \\
\hline Abdominal & $82(16.6)$ & $39(7.7)$ & $<0.001$ \\
\hline Bloodstream & $122(24.7)$ & $120(23.8)$ & 0.73 \\
\hline Renal/urinary tract & $82(16.6)$ & $58(11.5)$ & 0.02 \\
\hline Skin & $63(12.8)$ & $51(10.1)$ & 0.19 \\
\hline Catheter-related & $33(6.7)$ & $31(6.1)$ & 0.73 \\
\hline CNS & $9(1.8)$ & $26(5.1)$ & $<0.01$ \\
\hline Other & $63(12.8)$ & $76(15.0)$ & 0.29 \\
\hline
\end{tabular}

CNS, central nervous system.

${ }^{\mathrm{a}}$ Some patients had more than one site of infection, so percentages may total more than 100 .

Concomitant infection with Enterococcus, Pseudomonas spp., Acinetobacter spp. or Candida spp. was more frequent in MRSA-infected patients than in MSSA-infected patients (Table 3$)(7.7 \%$ vs. $4.4 \%, 15.4 \%$ vs. $11.5 \%, 8.9 \%$ vs. $3.6 \%$ and $15.0 \%$ vs. $10.5 \%$, respectively; all $P<0.05)$.

\subsection{Antibiotic therapy}

Almost all (96\%) of the patients in this cohort were treated with antibiotics. The distribution of antimicrobial drugs used on the study day is shown in Table 4. On the study day, $81.4 \%$ of MRSA-infected patients received at least one antibiotic usually 
active against MRSA, and $87.9 \%$ of MSSA-infected patients received at least one antibiotic usually active against MSSA.

Table 3. Concomitant infecting organisms in patients with meticillin-resistant Staphylococcus aureus (MRSA) and meticillin-sensitive S. aureus (MSSA) infections.

\begin{tabular}{|l|l|l|l|}
\hline Organism & MRSA [n (\%)] & MSSA [n (\%)] & P-value \\
\hline Gram-positive & \multicolumn{3}{l|}{} \\
\hline Staphylococcus epidermidis & $27(5.5)$ & $30(5.9)$ & 0.75 \\
\hline Streptococcus pneumoniae & $5(1.0)$ & $12(2.4)$ & 0.14 \\
\hline Enterococcus & $38(7.7)$ & $22(4.4)$ & 0.03 \\
\hline Other Gram-positive & $17(3.4)$ & $23(4.6)$ & 0.37 \\
\hline Gram-negative & & & \\
\hline Escherichia coli & $43(8.7)$ & $39(7.7)$ & 0.57 \\
\hline Enterobacter & $26(5.3)$ & $18(3.6)$ & 0.19 \\
\hline Klebsiella & $45(9.1)$ & $48(9.5)$ & 0.83 \\
\hline Pseudomonas & $76(15.4)$ & $58(11.5)$ & 0.04 \\
\hline Acinetobacter & $44(8.9)$ & $18(3.6)$ & $<0.001$ \\
\hline ESBL-producing & $3(0.6)$ & $2(0.4)$ & 0.68 \\
\hline Other Gram-negative & $46(9.3)$ & $50(9.9)$ & 0.75 \\
\hline Anaerobes & $12(2.4)$ & $12(2.4)$ & 0.96 \\
\hline Other bacteria & $1(0.2)$ & $0(0)$ & 0.49 \\
\hline Fungi & & & \\
\hline Candida & $74(15.0)$ & $53(10.5)$ & 0.03 \\
\hline Aspergillus & $6(1.2)$ & $7(1.4)$ & 0.81 \\
\hline Other fungi & $4(0.8)$ & $1(0.2)$ & 0.21 \\
\hline Parasites & $1(0.2)$ & $2(0.4)$ & 0.99 \\
\hline Other organisms & $1(0.2)$ & $0(0)$ & 0.49 \\
\hline ESBL, extended-spectrum $1-1 a c t a m a s e .1$ & & \\
\hline
\end{tabular}

ESBL, extended-spectrum $\beta$-lactamase.

\subsection{Factors associated with ICU and hospital mortality}

ICU mortality rates among patients with MRSA and MSSA infections were $29.1 \%$ and $20.5 \%$, respectively $(P<0.01)$ and corresponding hospital mortality rates were $36.4 \%$ and $27.0 \%(P<0.01)$. ICU and hospital mortality rates among western European patients $(n=518)$ with MRSA and MSSA infections were $29.4 \%$ and $16.7 \%(P<$ 
$0.001)$ and $39.3 \%$ and $22.8 \%(P<0.001)$, respectively. Corresponding numbers for other geographic areas were too small to yield any conclusive results.

Table 4. Antibiotic therapy on the study day in patients with meticillin-resistant Staphylococcus aureus (MRSA) and meticillin-sensitive S. aureus (MSSA) infections .

\begin{tabular}{|l|l|l|l|}
\hline Antibiotic & MRSA [n (\%)] & MSSA [n (\%)] & $P$-value \\
\hline Cephalosporin & $63(12.8)$ & $127(25.1)$ & $<0.001$ \\
\hline Penicillin & $99(20.0)$ & $253(50.1)$ & $<0.001$ \\
\hline Other $\beta$-lactams & $145(29.4)$ & $84(16.6)$ & $<0.001$ \\
\hline Aminoglycoside & $72(14.6)$ & $58(11.5)$ & 0.14 \\
\hline Quinolone & $72(14.6)$ & $89(17.6)$ & 0.19 \\
\hline Glycopeptide & $321(65.0)$ & $109(21.6)$ & $<0.001$ \\
\hline Macrolide & $15(3.0)$ & $28(5.5)$ & 0.05 \\
\hline Metronidazole & $32(6.5)$ & $28(5.5)$ & 0.54 \\
\hline Co-trimoxazole & $10(2.0)$ & $7(1.4)$ & 0.44 \\
\hline Oxazolidinone & $74(15.0)$ & $16(3.2)$ & $<0.001$ \\
\hline Daptomycin & $5(1.0)$ & $0(0)$ & 0.03 \\
\hline Tigecycline & $12(2.4)$ & $3(0.6)$ & 0.02 \\
\hline Antifungal & $92(18.6)$ & $58(11.5)$ & $<0.01$ \\
\hline Antiviral & $4(0.8)$ & $7(1.4)$ & 0.38 \\
\hline Other & $51(10.3)$ & $54(10.7)$ & 0.85 \\
\hline
\end{tabular}

${ }^{\mathrm{a}}$ Some patients received more than one antibiotic, so percentages may total more than 100.

Multivariate logistic regression analysis showed that SAPS II score [OR $=1.05,95 \%$ confidence interval $(\mathrm{Cl}) 1.04-1.07 ; P<0.001]$, Pseudomonas spp. infection $(\mathrm{OR}=$ $1.91,95 \% \mathrm{Cl} 1.20-3.60 ; P<0.01)$ and Acinetobacter infection $(\mathrm{OR}=3.15,95 \% \mathrm{Cl}$ 1.61-6.16; $P<0.001$ ) were associated with a higher ICU mortality risk. MRSA was not associated with an increased ICU mortality risk $(\mathrm{OR}=1.36,95 \% \mathrm{Cl} 0.94-1.97 ; P$ $=0.1)$. Age, chronic renal failure, SAPS II score, Pseudomonas infection, Acinetobacter infection and MRSA were independently associated with a higher hospital mortality risk (Table 5). 
Table 5. Multivariate logistic regression analysis with hospital mortality as the dependent variable.

\begin{tabular}{|c|c|c|}
\hline Variable & OR $(95 \%$ CI $)$ & $P$-value \\
\hline Age (per year) & $1.01(1.00-1.03)$ & 0.01 \\
\hline \multicolumn{3}{|l|}{ Type of admission } \\
\hline Surgery: elective & Ref. & \\
\hline Medical & $1.70(0.91-3.19)$ & 0.10 \\
\hline Surgery: emergency & $1.52(0.87-2.65)$ & 0.14 \\
\hline Trauma & $1.46(0.52-4.11)$ & 0.48 \\
\hline \multicolumn{3}{|l|}{ Source of admission } \\
\hline Operating room/recovery & Ref. & \\
\hline Emergency department/ambulance & $0.50(0.28-0.88)$ & 0.02 \\
\hline Hospital ward & $0.96(0.57-1.60)$ & 0.87 \\
\hline Other hospital & $0.82(0.46-1.47)$ & 0.51 \\
\hline Other & $1.21(0.41-3.58)$ & 0.73 \\
\hline SAPS II score (per point) & 1.05 (1.04-1.07) & $<0.001$ \\
\hline \multicolumn{3}{|l|}{ Co-morbid conditions } \\
\hline Chronic renal failure & $1.84(1.16-2.94)$ & 0.01 \\
\hline \multicolumn{3}{|l|}{ Type of microorganism } \\
\hline Pseudomonas spp. & $1.73(1.09-2.74)$ & 0.02 \\
\hline Acinetobacter spp. & $2.63(1.34-5.17)$ & $<0.01$ \\
\hline MRSA & $1.46(1.03-2.06)$ & 0.03 \\
\hline
\end{tabular}

OR, odds ratio; CI, confidence interval; SAPS, Simplified Acute Physiology Score; MRSA, meticillin-resistant Staphylococcus aureus.Hosmer-Lemeshow, $\chi^{2}=6.605 ; P=0.580$.

\section{Discussion}

The main findings of this study are that, in ICU patients, MRSA infections are more frequent in patients with underlying co-morbid conditions, such as cancer and chronic renal failure, and are associated with a 50\% greater likelihood of hospital death compared with MSSA infections. Patients with MRSA infection are also more likely to have concomitant infection with Pseudomonas spp., Enterococcus, Acinetobacter spp. or Candida spp. These findings are in agreement with several other studies $[6,7]$ and meta-analyses [2,4]. However, Kang et al. [7] reported that MRSA infection was 
only associated with increased mortality in patients with cancer or renal disease and in those with $S$. aureus bacteraemia, but not in their total cohort of 4974 patients with S. aureus infection. Unlike the current study, DeRyke et al. [11] reported no significant difference in attributable mortality between patients with MSSA infection and those with MRSA infection, although their study of healthcare-associated pneumonia was limited by the small sample size. In another more recent study on healthcare-associated $S$. aureus pneumonia, three of four patients were admitted to the ICU but there were no significant differences between MRSA and MSSA patients in terms of mortality [25/87 (29\%) vs. 11/55 (20\%)]; again the sample size was very small in this study [14]. The heterogeneity of the patient populations included in the different studies may also explain some of the apparent discrepancies in results $[8,9,11-14]$

We wanted to assess the burden of MRSA in a critically ill patient population. MRSA rates are known to vary over time in individual units and hospitals, emphasising the importance of conducting regular surveillance at local, regional and national levels with updated information on MRSA infections [1-4]. The rate of meticillin resistance in the $S$. aureus isolates in this study was ca. $50 \%$, similar to the $42 \%$ reported in the large Pan-American and European SENTRY surveillance study performed in 20052006 [18]. A study on Canadian ICU infections performed in 2005 and 2006 demonstrated that $90.7 \%$ of MRSA infections were due to healthcare-associated MRSA strains and 9.3\% were community-associated MRSA strains [19]. One limitation of the present study is that the protocol did not distinguish between community-acquired and healthcare-acquired infections. However, admission from the emergency room was more common among patients with MSSA, whereas 
admission from a hospital ward was more common among patients with MRSA, suggesting that hospital-acquired infections were likely more prevalent among patients with MRSA. This is also supported by the significantly longer median ICU stay prior to the study day for MRSA-infected patients compared with MSSA patients.

In this multivariate analysis, it was possible to demonstrate that age, chronic renal failure, SAPS II score, concomitant infection with Pseudomonas or Acinetobacter spp., and MRSA were independently associated with a higher risk of hospital mortality. Similar findings were also reported by Blot et al. [3] in a smaller number of critically ill patients with bacteraemia caused by $S$. aureus where acute renal failure, length of mechanical ventilation, age and meticillin resistance were independently associated with mortality. Owing to the transverse design of the current study, it was not possible to evaluate the relationship between MRSA infection and duration of mechanical ventilation.

The strength of this study is the large sample size. The study was not designed to evaluate potential mechanisms at the bacterial level but to discover global factors associated with the high mortality of MRSA infection. Increased MICs to vancomycin [20-22], delay in appropriate antimicrobial therapy [23-28], inferior bactericidal effect of vancomycin and suboptimal antibiotic dosage [29] are factors and mechanisms that may be involved in the increased mortality associated with MRSA infections, but we were unable to assess these. Another limitation of the study was that the diagnosis of infection versus colonisation was a clinical one. Moreover, antibiotic treatment was only noted on the day of the study and, therefore, data for full therapeutic comparisons are not available. Finally, the multivariate analysis is limited 
by the available variables, and the possible influence of other factors cannot be excluded.

In conclusion, we have demonstrated that in addition to age, SAPS II score, acute renal failure and concomitant infection with Pseudomonas or Acinetobacter spp., meticillin resistance was independently associated with higher hospital mortality rates among critically ill patients with S. aureus infections. Active surveillance for MRSA [30] and standard infection prevention measures must be encouraged in this high-risk patient group.

\section{Acknowledgment}

The authors thank Hassane Njimi, MSc, PhD (Department of Intensive Care, Erasme University Hospital, Brussels, Belgium) for help with data management and statistical analyses.

\section{Funding}

None.

\section{Competing interests}

JR participated as a consultant and as a member of the speaker's bureau for Pfizer. All other authors declare no competing interests.

\section{Ethical approval}


Ethics committee approval P2007/107, signed by Prof. P.A. Herchueltz and Mr G. Niset, Chairman and Secretary of the Ethics Committee of Erasme Hospital (Brussels, Belgium). 


\section{References}

[1] Kock R, Becker K, Cookson B, Gemert-Pijnen J, Harbarth S, Kluytmans J, et al. Methicillin-resistant Staphylococcus aureus (MRSA): burden of disease and control challenges in Europe. Euro Surveill 2010;15:19688.

[2] Whitby M, McLaws ML, Berry G. Risk of death from methicillin-resistant Staphylococcus aureus bacteraemia: a meta-analysis. Med J Aust 2001;175:2647.

[3] Blot SI, Vandewoude KH, Hoste EA, Colardyn FA. Outcome and attributable mortality in critically III patients with bacteremia involving methicillin-susceptible and methicillin-resistant Staphylococcus aureus. Arch Intern Med 2002;162:2229_ 35.

[4] Cosgrove SE, Sakoulas G, Perencevich EN, Schwaber MJ, Karchmer AW, Carmeli Y. Comparison of mortality associated with methicillin-resistant and methicillin-susceptible Staphylococcus aureus bacteremia: a meta-analysis. Clin Infect Dis 2003;36:53-9.

[5] Engemann JJ, Carmeli Y, Cosgrove SE, Fowler VG, Bronstein MZ, Trivette SL, et al. Adverse clinical and economic outcomes attributable to methicillin resistance among patients with Staphylococcus aureus surgical site infection. Clin Infect Dis 2003;36:592-8.

[6] Patel M, Weinheimer JD, Waites KB, Baddley JW. Active surveillance to determine the impact of methicillin-resistant Staphylococcus aureus colonization on patients in intensive care units of a Veterans Affairs Medical Center. Infect Control Hosp Epidemiol 2008;29:503-9. 
[7] Kang Cl, Song JH, Chung DR, Peck KR, Ko KS, Yeom JS, et al. Clinical impact of methicillin resistance on outcome of patients with Staphylococcus aureus infection: a stratified analysis according to underlying diseases and sites of infection in a large prospective cohort. J Infect 2010;61:299-306.

[8] Graffunder EM, Venezia RA. Risk factors associated with nosocomial methicillinresistant Staphylococcus aureus (MRSA) infection including previous use of antimicrobials. J Antimicrob Chemother 2002;49:999-1005.

[9] Cosgrove SE, Qi Y, Kaye KS, Harbarth S, Karchmer AW, Carmeli Y. The impact of methicillin resistance in Staphylococcus aureus bacteremia on patient outcomes: mortality, length of stay, and hospital charges. Infect Control Hosp Epidemiol 2005;26:166-74.

[10] Peres-Bota D, Rodriguez H, Dimopoulos G, DaRos A, Melot C, Struelens $\mathrm{MJ}$, et al. Are infections due to resistant pathogens associated with a worse outcome in critically ill patients? J Infect 2003;47:307-16. treatment, and outcomes of nosocomial bacteremic Staphylococcus aureus pneumonia. Chest 2005;128:1414-22. Wang JL, Chen SY, Wang JT, Wu GH, Chiang WC, Hsueh PR, et al. Comparison of both clinical features and mortality risk associated with bacteremia due to community-acquired methicillin-resistant Staphylococcus aureus and methicillin-susceptible S. aureus. Clin Infect Dis 2008;46:799-806. Healy DG, Duignan E, Tolan M, Young VK, O'Connell B, McGovern E. Should cardiac surgery be delayed among carriers of methicillin-resistant Staphylococcus aureus to reduce methicillin-resistant Staphylococcus aureus- 
related morbidity by preoperative decolonisation? Eur J Cardiothorac Surg 2011;39:68-74.

[14] Shorr AF, Haque N, Taneja C, Zervos M, Lamerato L, Kothari S, et al. Clinical and economic outcomes for patients with health care-associated Staphylococcus aureus pneumonia. J Clin Microbiol 2010;48:3258-62.

[15] Taneja C, Haque N, Oster G, Shorr AF, Zilber S, Kyan PO, et al. Clinical and economic outcomes in patients with community-acquired Staphylococcus aureus pneumonia. J Hosp Med 2010;5:528-34. International study of the prevalence and outcomes of infection in intensive care units. JAMA 2009;302:2323-9.

$$
\text { Calandra T, Cohen J. The International Sepsis Forum Consensus }
$$

Conference on Definitions of Infection in the Intensive Care Unit. Crit Care Med 2005;33:1538-48.

$$
\text { Fritsche TR, Sader HS, Jones RN. Antimicrobial activity of ceftobiprole, a }
$$
novel anti-methicillin-resistant Staphylococcus aureus cephalosporin, tested against contemporary pathogens: results from the SENTRY Antimicrobial Surveillance Program (2005-2006). Diagn Microbiol Infect Dis 2008;61:86-95. Zhanel GG, Decorby M, Nichol KA, Baudry PJ, Karlowsky JA, LagaceWiens PR, et al. Characterization of methicillin-resistant Staphylococcus aureus, vancomycin-resistant enterococci and extended-spectrum $\beta$-lactamase-producing Escherichia coli in intensive care units in Canada: results of the Canadian National Intensive Care Unit (CAN-ICU) study (2005-2006). Can J Infect Dis Med Microbiol 2008;19:243-9. 
Haque NZ, Zuniga LC, Peyrani P, Reyes K, Lamerato L, Moore CL, et al.; Improving Medicine through Pathway Assessment of Critical Therapy of Hospital-Acquired Pneumonia (IMPACT-HAP) Investigators. Relationship of vancomycin minimum inhibitory concentration to mortality in patients with methicillin-resistant Staphylococcus aureus hospital-acquired, ventilatorassociated, or health-care-associated pneumonia. Chest 2010;138:1356-62. Wang JL, Wang JT, Sheng WH, Chen YC, Chang SC. Nosocomial methicillin-resistant Staphylococcus aureus (MRSA) bacteremia in Taiwan: mortality analyses and the impact of vancomycin, MIC $=2 \mathrm{mg} / \mathrm{L}$, by the broth microdilution method. BMC Infect Dis 2010;10:159. Takesue Y, Nakajima K, Takahashi Y, Ichiki K, Ishihara M, Wada Y, et al. Clinical characteristics of vancomycin minimum inhibitory concentration of $2 \mu \mathrm{g} / \mathrm{ml}$ methicillin-resistant Staphylococcus aureus strains isolated from patients with bacteremia. J Infect Chemother 2011;17:52-7. Lodise TP, McKinnon PS, Swiderski L, Rybak MJ. Outcomes analysis of delayed antibiotic treatment for hospital-acquired Staphylococcus aureus bacteremia. Clin Infect Dis 2003;36:1418-23. Schramm GE, Johnson JA, Doherty JA, Micek ST, Kollef MH. Methicillinresistant Staphylococcus aureus sterile-site infection: the importance of appropriate initial antimicrobial treatment. Crit Care Med 2006;34:2069-74. Staphylococcus aureus in a Canadian Intensive Care Unit: delays in initiating effective therapy due to the low prevalence of infection. Can J Infect Dis Med Microbiol 2007;18:139-43. 
Rodriguez-Bano J, Millan AB, Dominguez MA, Borraz C, Gonzalez MP, Almirante B, et al. Impact of inappropriate empirical therapy for sepsis due to health care-associated methicillin-resistant Staphylococcus aureus. J Infect $2009 ; 58: 131-7$. Kumar A, Ellis P, Arabi Y, Roberts D, Light B, Parrillo JE, et al. Initiation of inappropriate antimicrobial therapy results in a fivefold reduction of survival in human septic shock. Chest 2009;136:1237-48. Marchaim D, Kaye KS, Fowler VG, Anderson DJ, Chawla V, Golan Y, et al. Case-control study to identify factors associated with mortality among patients with methicillin-resistant Staphylococcus aureus bacteraemia. Clin Microbiol Infect 2010;16:747-52. Giuliano C, Haase KK, Hall R. Use of vancomycin pharmacokineticpharmacodynamic properties in the treatment of MRSA infections. Expert Rev Anti Infect Ther 2010;8:95-106. Martinez-Capolino C, Reyes K, Johnson L, Sullivan J, Samuel L, Digiovine B, et al. Impact of active surveillance on meticillin-resistant Staphylococcus aureus transmission and hospital resource utilisation. J Hosp Infect 2010;74:232-7. 


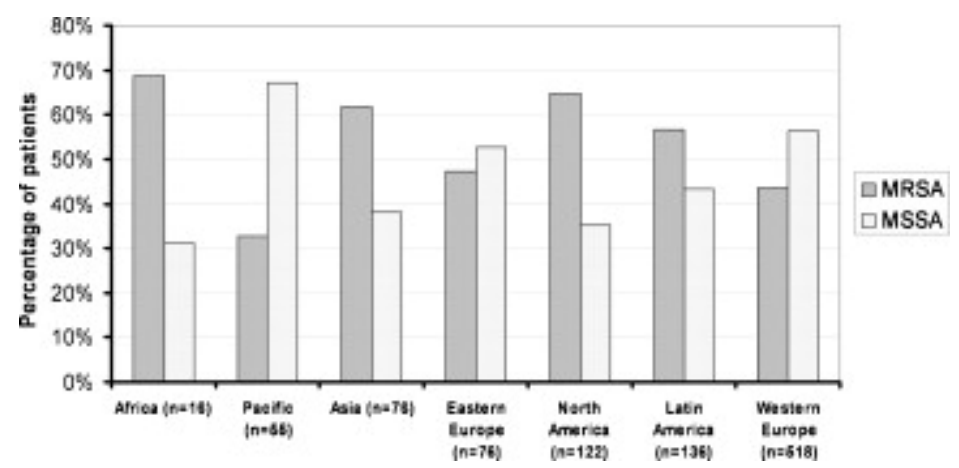

Fig. 1. Percentages of infected patients with positive Staphylococcus aureus cultures according to their sensitivity to meticillin in different geographical regions. MRSA, meticillin-resistant $S$. aureus; MSSA, meticillin-sensitive $S$. aureus. 


\section{Appendix}

\section{List of participating centres by country alphabetically}

Andorra: Hospital Nostra Senyora de Meritxell (A. Margarit).

Argentina: Centro de Educación Médica E Investigaciones Clínicas (R. Valentini); Clinica de Especialidades Villa Maria (Z. Alan Javier); Clínica Modelo de Morón (C. Bevilacqua); Clinica y Maternidad Suizo (M. Curone); CMIC (R. Rabuffetti); Hospital Aleman (P. Comignani); Hospital Argerich (M. Torres Boden); Hospital Britanico (F. Chertcoff); Hospital Central de San Isidro (G. Cardonatti); Hospital de Niños Dr Héctor Quintana (F. Adén); Hospital del Niño Jesús (L. Marcos); Hospital Dr Pedro Ecay (M. Dónofrio); Hospital Español de Mendoza (R. Fernández); Hospital Español Medical Plaza (R. Lamberghini); Hospital Internacional General de Agudos ‘José de San Matín’ (S. Balasini); Hospital Interzonal Dr O. Alende (J. Teves); Hospital Italiano de Buenos Aires (M. Las Heras, J. Sinner); Hospital Juan A. Fernández (D. Ceraso); Hospital Municipal de Chivilcoy (D. Curcio); Hospital Profesor Alejandro Posadas (L. Aguilar); Hospital Provincial de Rosario (C. Weller); Hospital Provincial del Centenario (L. Cardonnet); Hospital Regional Rio Gallegos (R. Santa Cruz); Hospital Regional Ushuaia (E. Manrique); Hospital Universitario Austral (D. Bernardez, T. Iolster); Hospital Universitario Universidad Abierta Interamericana (G. Chiappero); Instituto Privado del Quemado Med-Inter (D. Curcio); Nuevo Hospital El Milagro (P. Ramos); Ramos Mejia Hospital (J. Vergara); Sanatorio Agote (I. Moine); Sanatorio de la Trinidad Mitre (S. Ilutovich); Sanatorio de Los Arcos (G. Jannello); Sanatorio Dupuytren (M. Waschbusch); Sanatorio Frangioli de Salud 2000 Srl (G. Rios Picaza); Sanatorio Mater Dei (A. Raimondi); Sanatorio Otamendi y Miroli (M. Miriam); Sanatorio 
Parque (C. Lovesio); Sanatorio San José (D. Curcio); Centro Gallego de Buenos Aires (M. Caridi).

Australia: Alfred Hospital (T. Leong); Barwon Health (N. Orford); Blacktown Hospital (G. Reece); Box Hill Hospital (D. Ernest); Cabrini Hospital (F. Hawker); Concord Repatriation General Hospital (J. Tan); Epworth Eastern Private Hospital (C. Giannellis); Epworth Hospital Richmond (B. Ihle); Flinders Medical Centre (A. Bersten); Frankston Hospital (J. Mclnnes); Gold Coast Hospital (M. Tallott); John Hunter Hospital (B. McFadyen); Joondalup Health Campus (J. Vibert); Liverpool Hospital, Sydney South West Area Health Service (M. Parr); Logan Hospital (K. Tran); Mater Health Services (J. Sutton); Mount Hospital (S. Webb); Nambour General Hospital (N. Groves); Nepean Hospital, NSW (L. Cole); Prince Charles Hospital (D. Long); Prince of Wales Hospital (F. Bass); Princess Margaret Hospital for Children (S. Erickson); Royal Brisbane and Women's Hospital (J. Lipman); Royal Children's Hospital, Brisbane (D. Long); Royal Children's Hospital, Melbourne (C. Delzoppo); Royal Darwin Hospital (J. Thomas); Royal Perth Hospital (G. Dobb); Royal Prince Alfred Hospital (M. Daley); Sir Charles Gairdner Hospital (B. Roberts); St John of God Hospital, Subiaco (S. Webb); St Vincent's Hospital, Melbourne (J. Santamaria); Sydney Children's Hospital (J. Young); The Children's Hospital at Westmead, Sydney (M. Festa); The John Flynn Private Hospital (R. Holland); The Prince Charles Hospital (D. Mullany); The Queen Elizabeth Hospital (P. Williams); The Townsville Hospital (M. Corkeron); The Wollongong Hospital (M. Gales); Westmead Hospital (A. Banerjee); Women's and Children's Hospital, Adelaide (M. Yung).

Austria: University Hospital Innsbruck (N. Mutz, M. Hiesmayr); General Hospital (P. Faybik); Hospital Hietzing (R. Fitzgerald); Krankenhaus Barmherzige Brüder Linz (F. 
Firlinger); Krankenhaus der Barmherigen Brueder Wien (G. Zasmeta); Krankenhaus der Barmherzigen Brüder St Veit (M. Zink); Krankenhaus der Barmherzigen

Schwestern Linz (W. Sieber); Krankenhaus Steyr (J. Hildegard); Landeskrankenhaus Klagenfurt (R. Bakondy); Landeskrankenhaus Stolzalpe (J. Schlieber);

Landeskrankenhaus Deutschlandsberg (G. Filzwieser); Medical University Innsbruck (R. Beer, M. Joannidis); Medical University of Vienna (T. Staudinger); Otto-Wagner Hospital (R. Schuster); Unfallkrankenhaus Meidling Der Auva (W. Scherzer); University Hospital (K. Smolle); Wilhelminenspital (S. Fitzal).

Bangladesh: Central Hospital Limited (R. Manzoor).

Belgium: A.I.T. (J. Brunain); Ambroise Paré (A. D’Hondt); ASZ-Aalst (G. Huylenbroeck); AZ Groeninge Kortrijk (M. van der Schueren); AZ Maria Middelares (H. 't Kindt); AZ Sint Jozef Malle (E. Slock); AA Sint Lucas (D. Rijckaert); AZ St Augustinus (J. Raemaekers); AZ St Jan Av (M. Bourgeois); AZ Vesalius (I. Van Cotthem); AZ Damiaan Oostende (G. Nackaerts); CHNDRF (D. Gusu); Centre Hospitalier de Mouscron (P. Gadisseux); CHA Libramont (O. Vancollie); ChirecBraine-L'Alleud (H. Lignian); CHPLT Verviers (P. Michel); CHR Citadelle (V. Fraipont); CHR Haute Senne Soignies (M. Vander Stappen); CHR St Joseph MonsWarquignies (F. Forêt); CHU Brugmann (D. De Bels, J. Devriendt, J. Massaut); CHU Charleroi (P. Biston); CHU Saint-Pierre (A. Roman); CHU Sart Tilman, Liège (B. Lambermont); Clinique Sainte Elisabeth (A. De Meulder); Clinique Notre Dame (V. Frederic); Clinique Notre-Dame de Grâce (T. Sottiaux); Clinique Saint Luc, Bouge (P. Ruyffelaere); Cliniques de L'Europe, St-Michel (V. Collin); Cliniques de L'Europe, Ste Elisabeth (S. Anane); Hôpital Francais (P. Kleiren); Hôpital Saint-Joseph (M. Simon); CHHF, Hornu (S. Machayekhi); Imeldaziekenhuis (E. Frans); Institut Jules Bordet (G. Leroy, T. Berghmans); Jan Yperman Hospital (R. Joseph); Olv Ter Linden 
Ziekenhuis, Knokke (J. Eerens); Saint Luc University Hospital (P. Laterre); Sint Augustinus, Veurne (B. Lagrou); St Vincent (R. Rutsaert); St-Jozefkliniek BornemWillebroek (W. Pisarek); UCL Mont-Godinne (A. Dive); Universitair Ziekenhuis Gent (J. De Waele); University Hospital Brussels (H. Spapen); University Hospital of Liege (P. Damas); Erasme University Hospital (J.L. Vincent); ZNA Stuivenberg (M. Malbrain).

Belize: Universal Health Services, Medical Center (J. Hidalgo).

Brazil: Bandeirantes Hospital (M. Baptista); Barra Dor Hospital (D. Salgado); Biocor Instituto (M. Braga); Casa de Saude Sao Jose Caxias (C. Avila); Centro Hospitalar Unimed (G. Westphal); Centro Integrado de Atenção à Saúde-Unimed Vitória (E. Caser); Clínica São Vicente da Gávea (A. Alves); Complexo Hospitalar Santa Casa de Porto Alegre (G. Friedman); Erasto Gaertner Hospital (M. Luz); Federal University of São Paulo (M. Assuncao); Fundacao Hospital de Clinicas Gaspar Vianna (H. Reis); Fundação Hospitalar Do Estado de Minas Gerais-Fhemig (A. Gomes); Fundação Pio XII (U. Silva); UNIFESP (W. Nogueira Fh); Hopital das ClínicasFMUSP (S. El-Dash); Hospital Padre Albino-Faculdade de Medicina de Catanduva (J. Valiatti); Hospital Alberto Cavalcanti (A. Barbosa); Hospital Badim (C. Coelho); Hospital Cardiotrauma Ipanema (M. Knibel); Hospital Carlos Fernando Malzoni (C. Minelli); Hospital da Cidade de Passo Fundo (J. Caovilla); Hospital das Clínicas da Faculdade de Medicina de Ribeirão Preto da Universidade de São Paulo (G. Teixeira); Hospital das Clínicas, Universisty of São Paulo (A. Hovnanian); Hospital das Nacoes (A. Rea-Neto); Hospital de Base-Famerp (S. Lobo); Hospital de Clínicas Mario Lioni (M. Lugarinho); Hospital de Clínicas Niterói (P. Souza); Hospital de Doenças Tropicais de Goiânia (D. Ferreira); Hospital do Cancer/Uopeccan (P. Duarte); Hospital do Trabalhador (M. Oliveira); Hospital dos Servidores do Estado 
Rio de Janeiro (J. Marques); Hospital e Maternidade São José (R. Machado); Hospital Estadual Diadema (P. Rehder); UNISA-Universidade de Santo Amaro (S. Mataloun); Hospital Evangelico (M. Grilo); Hospital Evangelico do Rio de Janeiro (P. Quesado); Hospital Geral de Pedreira (M. Moock); Hospital Geral de São Mateus (F. Ferreira); Hospital Geral Roberto Santos (J. Teles); Hospital Israelita Albert Einstein (E. Silva); Hospital Israelita Albert Sabin (C. Coelho); Hospital Júlia Kubitschek (A. Morais); Hospital Mater Dei (F. Bruzzi de Carvalho); Hospital Memorial Arthur Ramos (M. Wanderley); Hospital Meridional (M. Velasco); Hospital Moinhos de Vento (N. Brandão da Silva); Hospital Municipal São José (J. Feijó); Hospital Nossa Senhora da Salete (P. Duarte); Hospital Pasteur (V. Souza Dantas); Hospital Português (J. Teles); Hospital Pró-Cardíaco (R. Costa Filho); Hospital Quinta D’Or (A. Japiassú); Hospital Regional Antônio Dias (D. Villela); Hospital Regional de Barbacena (C. Santos); Hospital Salvador (R. Passos); Hospital Samaritano Sao Paulo (R. AlheiraRocha); Hospital Santa Izabel (R. Silva); Hospital Santa Paula (J. Houly); Hospital Sao Cristovao (J. Aldrighi); Hospital São Lucas (R. Hatum); Hospital São Lucas da PUCRS (F. Suparregui Dias); Hospital São Luiz-Unidade Itaim (L. Ferreira); Hospital São Rafael (L. Ferro); Hospital São Vicente de Paulo (J. Gomez); Hospital Universitário Clementindo Fraga Filho-Ufrj (R. Fleury); Hospital Universitario da Universidade Federal do Rio de Janeiro (C. David); Hospital Universitário de Santa Maria (T. Resener); Hospital Universitário do Oeste do Paraná (P. Duarte); Hospital Universitário Lauro Wanderley-UTI Adulto (C. Mendes); Hospital Universitario Regional de Maringa (A. Germano); Hospital Vita Curitiba (M. Oliveira); Hospital Vivalle (F. De Marco); Instituto de Pesquisa Clínica Evandro Chagas-FIOCRUZ (A. Japiassú); Instituto Do Coração-HC-FMUSP (S. Lage); Instituto Nacional de Cancer (J. Salluh); Irmandade Santa Casa de Misericordia de Porto Alegre (A. Torelly); 
Luxemburgo Hospital (R. Sad); Mternidade Odete Valadares (A. Barbosa); Prontocor Lagoa (G. Oliveira); Samaritano Hospital Rio de Janeiro (R. Lima); Santa Casa Da Misericórdia de São João del Rei (J. Paranhos); Santa Casa de Misericordia de Passos (M. Oliveira); Santa Casa de Porto Alegre (M. Rocha); São Sebastião Hospital (W. Bitencourt); Universidade Federal do Parana (A. Rea-Neto); University of Londrina (C. Grion); University of São Paulo (D. Forte); UTI da Disciplina de Clínica Médica-Unifesp (H. Guimarães); Vitória Apart Hospital (C. Piras).

Bulgaria: Mbal Ruse (L. Stephanova); Multiprofile Hospital of Active Treatment, Ruse (L. Lyubenov); Uh St Ekaterina (G. Tsarianski); University Hospital (G. Dimov). Canada: Capital Health-Queen Elizabeth II Health Sciences Centre (R. Green); Centre Hospitalier Régional de Lanaudière (J. Levasseur); Children's Hospital of Eastern Ontario (R. Ward); CHU Sherbrooke (O. Lesur); Hôpital Charles Lemoyne (G. Poirier); Mount Sinai Hospital (R. Wax); Royal Jubilee Hospital (G. Wood); St Joseph's Healthcare (D. Cook); St Michael's Hospital (J. Marshall); Toronto General Hospital (M. Herridge); Toronto Western Hospital (N. Ferguson); Victoria General Hospital (G. Wood).

Chile: Clinica Alemana de Santiago (M. Espinoza); Clinica las Condes (S. Valdés Jimenez); Hospital Clínico de la Pontificia Universidad Católica de Chile (A. Bruhn); Hospital del Trabajador (J. Micolich); Hospital Dr G. Fricke (S. Galvez); Hospital El Pino (I. Escamilla Leon).

China: Beijing Chaoyang Hospital (Q. Zhan); Beijing Tongren Hospital (Y. Xu); Chinense Pla General Hospital (Y. Zhao); Fuxing Hospital, Capital Medical University (L. Zhang); Guangdong Provincial People's Hospital (T. Qin); Peking Union Medical College Hospital (B. Du); Peking University People's Hospital (M. Li); Ren Ji Hospital, Shanghai Jiao Tong University (X. Wang); The Affiliated Hospital of Ningxia Medical 
College of China (Y. Jing); The First Affiliate Hospital of China Medical University (Z. Zhang); The First Affiliated Hospital of Dalian Medical University (W. Xianyao); The First People's Hospital of Nantong, Jiangsu (F. Li); Zhong-Da Hospital and School of Clinical Medicine, Southeast University (Y. Congshan).

Colombia: Clinica General del Norte (C. Rebolledo); Clinica Central del Quindio (D. Diaz); Clinica Medellin (R. Murillo Arboleda); Clinica Saludcoop (C. Rebolledo); Clinica Santa Isabel de Valledupar (A. Arias Antun); Fundación Hospital San Carlos (G. Montenegro); Fundacion Valle de Lili (M. Granados); Hospital Bocagrande de Cartagena (C. Dueñas); Hospital Departamental de Villavicencio (N. Perez); Hospital El Tunal (G. Libreros Duque); Hospital San Jose de Bogota (M. Coral); Hospital Santa Clara (G. Ortiz).

Costa Rica: Hospital Calderón Guardia CCSS (D. Rodriguez).

Croatia: Hospital for Infectious Diseases (B. Barsic); Sveti Duh General Hospital, School of Medicine, Zagreb (M. Cubrilo-Turek); University Hospital Centre (I. Gornik); University Hospital Zagreb (M. Grljusic).

Cuba: Hospital Universitario Arnaldo Milian Castro (A. Caballero Lopez); Hospital Universitario Dr Gustavo Aldereguía Lima (M. Iraola Ferrer).

Czech Republic: Centre of Cardiovascular and Transplant Surgery (P. Pavlik); Charles University Teaching Hospital, Hradec Kralove (J. Manak); Charles University Medical School and Teaching Hospital (J. Radej); Faculty General Hospital, Charles University Prague (J. Belohlavek); Faculty Hospital Brno (P. Sevcik); Faculty Hospital Olomouc (L. Blahut); General Teaching Hospital of 1st Faculty and Charles University (D. Tyl); Horovice Hospital (J. Steinbach); Klaudians Hospital (I. Herold); Krajska Nemocnice Liberec (I. Zykova); Nemocnice V Usti Nad Orlici (D. Prchal); St Anne's University Hospital Brno (T. Bartosik); University Hospital Brno (M. Kolarova); 
University Hospital Olomouc (R. Hájek, J. Kohoutová, O. Marek); University Hospital Ostrava (P. Hon); University Hospital PIzen (I. Chytra).

Denmark: Århus University Hospital (H. Betsch); Næstved Hospital (B. Fogh); Rigshospitalet (K. Espersen); Sygehus Fyn (K. Jacobsen); Vejle Sygehus (P. Berezowicz).

Ecuador: Carlos Andrade Marín Hospital (F. Guerrero); Clinica La Merced (E. Salgado); Hospital Eugenio Espejo (D. Barahona); Hospital General de Las Fuerzas Armadas del Ecuador Hg-1 (H. Del Pozo Sanchez); Hospital Metropolitano (M. Jibaja).

Egypt: Dar Alfouad Hospital (A. Alansary).

Estonia: East Tallinn Central Hospital (A. Reintam); Tartu University Hospital (J. Starkopf).

Finland: Helsinki University Central Hospital (V. Harjola).

France: AP-HP, CHU Jean Verdier (L. Tual); Assistance Publique-Hôpitaux de Marseille, CHU Nord (M. Leone); Centre Hospitalier Dunkerque (M. Serge); Centre Hospitalier Universitaire (P. Michel); Centre Hospitalier de Tourcoing (O. Leroy); Centre Hospitalier D’Auch (L. Mallet); Centre Hospitalier de Blois (B. Marc); Centre Hospitalier de Fougères (D. Dormoy); Centre Hospitalier de Niort (H. Pascal); Centre Hospitalier Dr Schaffner (L. Tronchon); Centre Hospitalier du Pays D’Aix (B. Garrigues); Centre Hospitalier Region Annecy (C. Santré); Centre Hospitalier Universitaire Amiens (H. Dupont); Centre Hospitalier Universitaire de Bicêtre (J. Duranteau); Centre Hospitalier Universitaire Reims (A. Leon); CH Colmar (L. Henry); CHG Armentieres (C. Canevet); CHU Angers (L. Dube); CHU Angers (H. Julien); CHU Bicetre (A. Nadia); CHU Brest (B. Francois); CHU de Bordeaux (J. Gérard); CHU Dijon Hopital Général (M. Freysz); CHU Hôtel Dieu-APHP (G. Remy); CHU 
Nantes (Y. Blanloeil); Clinique Ambroise Paré (P. Squara); Chalons en Champagne General Hospital (J.M. Korach); Grenoble University Hospital (M. Durand); Groupe Hospitalier du Havre (C. Gabriel); Hia Laveran (P. Eric); Hopital Antoine Béclère APHP (F. Jacobs); Hopital Bichat (R. Bronchard); Hôpital Claude Huriez, Centre Hospitalier Régional Universitaire de Lille (E. Kipnis); Hopital Cochin Paris (M. Moussa); Hôpital de Hautepierre (A. Launoy); Hopital de la Croix Rousse (C. Guérin); Hôpital Edouard Herriot (P. Vanhems); Hôpital Maison Blanche (A. Wynckel); Hôpital Raymond Poincaré (B. Clair); Hôpital Saint-Louis (E. Azoulay); Hôpital Tenon (J. Fulgencio); Hôpitaux Civils de Colmar (Y. Gottwalles); Hôpitaux Universitaires de Strasbourg (T. Krummel); Hospices Civils de Lyon (A. Lepape); La Rochelle Hospital (O. Lesieur); Lariboisiere University Hospital (D. Payen); Poissy Hospital (O. Hérvé); Polyclinique Saint André (J. Farkas); Rangueil Hospital (P. Cougot); Réanimation chirurgicale CHU Rennes (Y. Mallédant); University Hospital of Bordeaux HautLèvéque (O. Joannes-Boyau).

Germany: Academic Hospital Solingen (T. Standl); Ameos Klinikum St Salvator Halberstadt GmbH (U. Sierig); Asklepios Fachkliniken München-Gauting (J. Geiseler); Asklepios Klinik Langen (H. Hopf); Behandlungszentrum Vogtareuth (M. Burgau); Bergmannsheil Bochum (E. Conrad-Opel); Bethanien-Krankenhaus (C. Hermann); Bundeswehrkrankenhaus UIm (M. Ventzke); Charite Campus Virchow (T. Henneberg, F. Esposito); Charite Campus Berlin-Buch (H. Loeser); Charite Campus Mitte (C. Spies, H. Zuckermann-Becker); Charite Campus Benjamin Franklin (S. Voegeler); Clemenshospitl (R. Scherer); Dominikus Krankenhaus (A. Pauer); DrkKliniken Mark Brandenburg (S. Kljucar); Drk-Krankenhaus Ratzeburg (K. Delfs); Elisabeth-Krankenhaus Essen (.E Blank); Ev. Kliniken Bonn Betriebsstätte Waldkrankenhaus (J. Busch); Ev.-Freikirchliches Krankenhaus Rüdersdorf (K. 
Wendt); Evang. Krankenhaus Mülheim (J. Leßmann); Evangelische Kliniken Bonn Wadkrankenhaus (J. Busch); Evangelisches Krankenhaus Bielefeld (F. Bach); Friedrich Schiller University, Jena (Y. Sakr); Gemeinschaftskrankenhaus Herdecke (T. Berlet); Georg-August University of Göttingen (A. Kernchen); Georg-AugustUniversity of Göttingen (M. Quintel); Hanse-Klinikum Wismar (D. Holst); Heart Clinic of the University of Munich (E. Kilger); Helfenstein Klinik (T. Holubarsch); Helios Klinik Lengerich (C. Raufhake); Helios-Klinikum Berlin-Buch (R. Kuhlen, C. Stolt); Helios Klinikum Emil Von Behring (A. Lubasch); Helios Klinikum Erfurt GmbH (A. Meier-Hellmann); Helios Klinikum Wuppertal Barmen (G. Woebker); Henriettenstift (C. Scharnofske); Herz-Jesu-Krankenhaus (M. Breyer); Hochtaunus Kliniken Bad Homburg (T. Risch); Hospital Links Der Weser (C. Manhold); ICU in Drk Kliniken Mark Brandenburg (S. Kljucar); J.W. Goethe-University Medical School Frankfurt Am Main (D. Meininger); Johanniter Krankenhaus Bonn (C. Greive); Johanniter Krankenhaus Stendal gGmbH (J. Rau); Jung-Stilling-Krankenhaus (A. Seibel); Katharinenhospital (A. Henn-Beilharz); Katholisches Krankenhaus Hagen (R. Wolbert); Krankenhaus Prignitz Gemmeinnützige GmbH (T. Scherke); Klinik Am Eichert (J. Martin); Klinik für Herzchirurgie, Karlsruhe (M. Rudolph); Klinik Füranästhesie, Operative Intensivmedizin U. Schmerztherapie (J. Gleißner); Kliniken Ludwigsburg-Bietigheim GmbH (M. Wolf); Kliniken Maria Hilf (F. Schleibach); Klinikum Augsburg (U. Jaschinski); Klinikum Bad Salzungen (A. Lunkeit); Klinikum Darmstadt (M. Welte); Klinikum der J.W. Goethe-Universität (T. Bingold); Klinikum der Stadt Wolfsburg (K. Sydow); Klinikum Emden (K. Kogelmann); Klinikum Forchheim (F. Fischer); Klinikum Fuerth (B. Fischer, M. Schmid); Klinikum Grosshadern, Universität München (M. Klein); Klinikum Harlaching Städtisches Klinikum Muenchen (A. Bechtold); Klinikum Hildesheim (K. Bodmann); Klinikum 
Kaufbeuren (J. Klasen); Klinikum Landsberg (H. Meyrl); Klinikum Lippe-Detmold (J. Goetz); Klinikum Ludwigsburg (G. Geldner); Klinikum Luedenscheid (T. Helmes); Klinikum Meiningen GmbH (N. Jensen); Klinikum Minden (H. Eickmeyer, W. Lengfelder); Klinikum Nürnberg (B. Langenstein); Klinikum Rechts Der Isar (R. Bogdanski); Klinikum Rechts Der Isar Der Technischen Universität München (S. Jelen-Esselborn, A. Umgelter); Klinikum Region Hannover (F. Dörr); Klinikum Region Hannover Krankenhaus Großburgwedel (K. Lüttje); Klinikum Region Hannover, Krankenhaus Oststadt-Heidehaus (D. Heinemeyer); Klinikum Starnberg (M. Uhl); Klinikum Stuttgart-Olgahospital (P. Schirle); Klinikum Suedstadt (H. Benad); Klinikum Traunstein (M. Glaser); Klinikum Uelzen (W. Panzer); Klinikum Worms (E. Huettemann); Klinikverbund St Ansgar, Krankenhaus Bassum (R. Stierwaldt); Klinikverbund Süd-West (M. Schappacher); Knappschaftskrankenhaus BochumLangendreer (E. Müller); Krankenhaus Freyung (Rural Hospital) (W. Stadlmeyer); Krankenhaus Lübbecke (M. Fantini); Krankenhaus Mol GmbH Strausberg (B. Dummer); Krankenhaus Nordwest (M. Thörner); Krankenhaus Nordwest (V. Jost); Krankenhaus Reinbek (T. Loerbroks); Kreisklinik Trostberg (T. Glück); Kreiskrankenhaus Bergstrasse (R. Zimmermann); Kreiskrankenhaus Calw (R. Clement); Kreiskrankenhaus Mechernich GmbH (R. Hering); Kreiskrankenhaus Nagold (T. Klinger); Kreiskrankenhaus Rottweil (J. Mehl); Kreiskrankenhaus St Marienberg Helmstedt (H. Polozek); Leopoldina-Krankenhaus (A. Rothhammer); Ludmillenstift (R. Seidler); Lukas-Krankenhaus Bünde (P. Lorenz); Lungenfachklinik Amsee Waren Mueritz (M. Lutze); Marienhospital Bruehl (M. Euler); Marienkrankenhaus Schwerte (M. Heintz); Martin Luther Universität Halle (M. Winkler); Medizinische Klinik (M. Angstwurm); Mlu Halle-Wittenberg (K. Krohe); Mueritz-Klinikum Waren (T. Treu); Neurological Intensive Care Unit (T. Steiner); 
Oberschwabenklinik Wangen (S. Locher); Orthopädische Klinik Markgröningen (A. Walz); Ostalb-Klinikum Aalen (P. Zahn); Otto-Von-Guericke Universität Magdeburg (W. Brandt); Scivias-Krankenhaus St Josef (M. Marks); Ska-Bileelfeld-Mitte (F. Henning); St Antonius Hospital (U. Janssens); St Hildegardis Krankenhaus Mainz (M. Luethgens); St Johannes Krankenhaus (W. Theelen); St Johannes-Hospital (M. Sydow); St Johannes-Hospital (M. Weber); St Josef-Hospital, Ruhr-Universität Bochum (A. Meiser); St Josefs-Hospital (C. Deutschmann); St Joseph Krankenhaus (C. Buttner); St-Marien Hospital Lünen (M. Jokiel); St Marienhospital Hamm (C. Bozzetti); St Vincentius Kliniken (B. Jürgen); St-Elisabeth Krankenhaus KölnHohenlind (F. Fiedler); St-Vincentius-Krankenhaus Speyer (K. Wresch); Städtischen Kliniken Neuss-Lukaskrankenhaus (A. Kremer); Städtisches Klinikum Karlsruhe (H. Bleier); Städtisches Klinikum Wiesbaden, Dr-Horst-Schmidt-Kliniken Hsk (M. Rueckert); Staedtisches Klinikum Guetersloh (H. Ditter); Staedtisches Klinikum Muenchen GmbH-Klinikum Harlaching (C. Peckelsen); Staedtisches Klinikum Muenchen $\mathrm{GmbH} /$ Klinikum Bogenhausen (P. Friederich); Staedtisches Klinikum München-Klinikum Neuperlach (K. Weber); Tübingen University Hospital (W. Krueger); Ubbo-Emmius-Klinik Aurich (R. Lowack); Überlingen Hospital (A. Michalsen); Uniklinikum Dresden (M. Ragaller); Universitaetsklinikum des Saarlandes (A. Groeschel); Universitaetsklinikum Mannheim (T. Friedrich); Universität Rostock (M. Hinz); Universitätsklinikum Der Martin-Luther-Universität Halle-Wittenberg (A. Christel); Universitätsklinikum Dresden Carl Gustav Carus (M. Ragaller); Universitätsklinikum Leipzig Aör (T. Hartwig, U. Kaisers, D. Schmitt); Universitätsmedizin Berlin Charité Campus Benjamin Franklin (S. Vögeler); University (M. Weiss); University Children's Hospital Hauner (K. Reiter); University Hospital (T. Schwab); University Hospital Cologne (U. Trieschmann); University 
Hospital Dusseldorf (D. Kindgen-Milles); University Hospital Giessen and Marburg GmbH-Giessen (J. Engel); University Hospital Lübeck (B. Sedemund-Adib); University Hospital Mainz (M. Lauterbach); University Hospital Marburg (M. Max); University Hospital Muenster (T. Volkert); University Hospital of Essen (C. Waydhas); University Hospital of Mannheim (S. Hien); University Hospital of Munich, LMU (J. Briegel); University Hospital of Regensburg (V. Guralnik); University Hospital Rwth Aachen (N. Zoremba); University Hospital Tübingen (R. Riessen); University Hospital Würzburg (W. Müllges); University Medical Center Hamburg-Eppendorf (A.

Nierhaus); University of Erlangen (R. Strauss); University of Freiburg (S. Utzolino); University of Giessen (J. Thul); University of Greifswald (P. Abel, M. Gründling, W. Keßler); University of Heidelberg (K. Scheuren); University of Rostock (D. Vagts); University of Saarland (H. Rensing); University Hospital Essen (B. Schoch); University Hospital (K. Kopp); Vivantes-Klinikum Neukoelln (H. Gerlach); Vivantes Klinikum Prenzlauer Berg (M. Corea); Vivantes-Klinikum Am Urban (A. Uhrig); Westkuestenklinikum Heide (S. Schroeder); Westküstenklinikum Heide (F. Jordan); Westpfalz-Klinikum Kaiserslautern (T. Huber); Zentralöklinikum Augsburg (M. Bittinger).

Greece: Ahepa University Hospital (E. Sofianos); Athens University Medical School (A. Armaganidis); Evangelismos Hospital (C. Routsi); G. Papanikolaou (M. Bitzani); General Hospital of Rethymno (A. Chalkiadaki); Henry Dunant Hospital (A. Michalopoulos); Hippokrateion Hospital Thessaloniki (E. Mouloudi); Kat General Hospital (E. loannidou); Kat Hospital (P. Myrianthefs); Kat Hospital, Athens (D. Koulenti); Konstantopoulio General Hospital (I. Karampela); Lamia General Hospital (G. Kyriazopoulos); Red Cross Hospital of Athens (K. Mandragos); Thriassio Hospital of Eleusis (P. Clouva-Molyvdas); University Hospital of loannina (A. Moraiti); 
University Hospital of Alexandroupolis (I. Pneumatikos); University Hospital of Rion,

Patras (K. Filos); University Hospital of Thessaly (Larissa) (E. Zakynthinos);

University of Athens, Medical School (A. Kotanidou); Xanthi General Hospital (A. Vakalos).

Hong Kong: North District Hospital (A. Cheng); Princess Margaret Hospital and Yan Chai Hospital (T. Buckley); The Chinese University of Hong Kong (C. Gomersall). Hungary: National Institute of Neurosurgery (K. Kiss); Péterfy Hospital Budapest (P. Tamási); Saint George Hospital Hungary (A. Sarkany); Semmelweis University (A. Csomos); University of Szeged (É. Zöllei).

India: Advanced Medicare Research Institute (S. Todi); B.D. Petit Parsee General Hospital (F. Udwadia); Bhailal Amin General Hospital (R. Shah); Bombay Hospital (P. Amin); Breach Candy Hospital Trust (F. Udwadia); Care Hospitals (S. Samavedam); Christian Medical College (A. Mathai); Cumballa Hill Hospital \& Heart Institute (M. Patil); Deenanath Mangeshkar Hospital (S. Jog); Dr S.N. Medical College (M. Gurjar); Escorts Heart Institute \& Research Centre (M. Vats); Fortis Healthcare (A. Varma); Global Hospitals (P. Gopal); Hinduja Hospital \& Medical Research Center (F. Kapadia); Indraprastha Apoolo Hospitals (R. Chawla); Jehangir Hospital (S. Iyer); Kalinga Hospital (S. Sahu); Kasturba Hospital (C. Bakshi); Lokmanya Care Hospital (D. Ambike); Max Super Speciality Hospital (D. Govil); Medical Trust Hospital, Cochin (V. Karipparambath); Nh Hospital (J. Chacko); Ruby Hall Clinic (P. Sathe); Rungta Hospital (N. Rungta); Saifee Hospital (C. Jani); Seth Ramdas Shah Memorial Hospital \& Research Centre (A. Bhome); Shree Medical Foundation (S. Prayag); Sir Ganga Ram Hospital (S. Ray); Sundaram Medical Foundation (R. Rajagopalan); Tata Memorial Hospital (J. Divatia); Wockhardt Hospital (R. Da Costa); Wockhrdt Hospital (T. Shyam Sunder). 
Indonesia: Bintaro International Hospital (P. Wibowo); Hasan Sadikin Hospital (T. Maskoen); Pantai Indah Kapuk Hospital (T. Sugiman).

Ireland: Amnch (M. Donnelly); Cork University Hospital (D. Breen); Mater Misercordiae University Hospital (S. Ng); University Hospital Galway (J. Bates). Islamic Republic of Iran: Imamreza Hospital (S. Nowruzinia); Laleh Hospital (A. Lotfi); Tehran University of Medical Sciences (A. Mahmoodpoor).

Israel: Hadassah Medical Center (C. Sprung); Haemek Medical Center (A. Lev); Kaplan Medical Center (E. Kishinevsky); Rabin Medical Center (J. Cohen); Soroka Medical Center (S. Sofer).

Italy: A.O. Niguarda (S. Vesconi); A.O. Ospedale Di Circolo Di Busto Arsizio (S. Greco); A.O. Treviglio-Caravaggio (M. Borelli); Anestesia E Rianimazione 2 Prof. de Gaudio (P. Cecilia); Arnas Ospedale Civico (M. Sapuppo); ASL 10 (A. Lazzero); ASL 10 Florence Hospital San Giovanni Di Dio (V. Mangani); Azienda Ospedaliera Desenzano (N. Petrucci); Azienda Ospedaliera Di Melegnano (M. Minerva); Azienda Ospedaliera G. Rummo (E. De Blasio); Azienda Ospedaliera Polo Universitario San Paolo (S. Marzorati); Azienda Ospedaliera Santa Maria Alle Scotte (R. Rosi); Azienda Ospedaliera Universitaria P. Giaccone Policlinico (A. Giarratano); Azienda Ospedaliera-Universitaria Udine (O. Margarit); Azienda Ospedaliero-Universitaria (A. Guberti); Azienda Ospedaliero-Universitaria S.M. Misericordia (S. Scolz); Clinica San Gaudenzio (E. Stelian); Fondazione IRCCS Policlinico San Matteo (V. Emmi); Fondazione Ospedale Maggiore Policlinico, Mangiagalli Regina Elena (M. Caspani); Fondazione Poliambulanza (A. Rosano); H. San Gerardo (C. Abbruzzese); Hospital Panico Tricase (S. Colonna); Humanitas Gavazzeni (R. Ceriani); Il Faculty of Medicne I University of Rome-Osp. S. Andrea (R. De Blasi); S. Salvatore Hospital (L. Panella); IRCCS Casa Sollievo Della Sofferenza (F. Borrelli); Istituto Nazionale 
Tumori Regina Elena (P. Lorella); KH Brixen (H. Ruatti); Ospedali Riuniti di Ancona (C. Munch); Ospedale 'Ca Foncello'-Treviso (Italia) (C. Sorbara); Ospedale 'Santa Croce'-ASL 8 (G. Fiore); Ospedale Bufalini-Cesena (A. Chieregato); Ospedale Di Circolo E Fondazione Macchi (V. Conti); Ospedale Di Massa (A. Guadagnucci); Ospedale Piacenza (M. Pizzamiglio); Ospedale Ferrarotto (M.T. Locicero); Ospedale Maggiore Ausl Bologna (I. Marri); Ospedale Maggiore Policlinico Milano (A. Sicignano); Ospedale Maggiore Policlinico, Mangiagalli E Regina Elena, IRCCS Milano (V. Conte); Ospedale Mugello Azienda Sanitaria Firenze (R. Oggioni); Ospedale Niguarda Ca Granda, Milano (A. De Gasperi); Ospedale Oncologico Regionale-Centro Di Riferimento Oncologico Della Basilicata (P. De Negri); Ospedale Provinciale Pistoia (G. Santagostino); Ospedale S. Gerardo (F. Roberto); Ospedale San Raffaele (G. Marino); Ospedele Vittorio Emanuele (G. Castiglione); P.O. San Severo AsI Fg (D. Sforza); S. Camillo Hospital (N. Giuseppe); San Martino Hospital, Genoa (M. Bassetti); Seconda Università Degli Studi Di Napoli (F. Ferraro); Sesto San Giovanni Hospital (S. Clementi); Teaching Hospital Careggi (A. Di Filippo); Terapia Intensiva-Aso S. Giovanni Battista Di Torino-Ospedale Molinette (P. Cotogni, M.V. Ranieri); Università Cattolica (M. Antonelli); Universita' Cattolica Del S. Cuore (L. Martinelli); University-Hospital Careggi, Florence (L. Gianesello); University Hospital Policlinico Di Catania (A. Gullo); University of Rome 'La Sapienza' (A. Morelli); UTI Trapianti (G. Biancofiore); University of Udine (G. Della Rocca). Japan: Kyoto Prefectural University of Medicine (S. Hashimoto); Nagoya University Hospital (M. Onodera); Oosaka-Fu Saiseikai Suita Hospital (A. Kobayashi); Sanai Hospital (T. Shinozuka); Tokushima University School of Medicine (H. Imanaka); Tokyo Medical University, Hachioji Medical Center (T. Ikeda); Tokyo Women's Medical University (A. Yaguchi). 
Latvia: Hospital of Traumatology and Orthopedics (I. Misane); 7th Hospital of Riga (A. Piebalga).

Lebanon: Lebanese Canadian Hospital (A. Moughaghab).

Lithuania: Medicine University of Kaunas (V. Pilvinis); Vilnius University Emergency Hospital (S. Vosylius); Vilnius University Hospital Santariskiu Clinics (M. Balciunas, G. Kekstas).

Luxembourg: Centre Hospitalier de Luxembourg (H. Margaret); Clinique Ste Thérèse (M. Klop).

Macedonia: Clinic for Infectious Diseases (K. Grozdanovski); General Hospital Stip (B. Eftimova).

Malaysia: Faculty of Medicine, Universiti Kebangsaan Malaysia (S. Wafa); Hospital Pulau Pinang (C. Lim); Hospital Tengku Ampuan Afzan, Kuantan, Pahang (M. Mat Nor); Kuala Lumpur Hospital (L. Tai); National Heart Institute (S. Syed Mohd Tahir); Sarawak General Hospital (N. Idris); Sultanah Aminah Hospital (C. Tan).

Malta: St Luke's Hospital (M. Borg).

Mexico: Angeles Metropolitano Hospital (E. Manzo); Centro Medico Lic. Adolfo Lopez Mateos (H. Gutierrez Morales); Hgr 25 Imss Zaragoza (P. Miguel); Hospital Angeles Clinica Londres (A. Villagomez); Hospital Angeles del Carmen (A. Bassols); Hospital Civil de Guadalajara 'Fray Antonio Alcalde' (G. Aguirre); Hospital Español de México (U. Cerón); Hospital General Bernardo J. Gastelum (J. Lopez Ramos); Hospital General del Estado ‘Dr Ernesto Ramos Bours', Hermosillo Sonora Mexico (J. Monjardín); Hospital General Regional de Leon (E. Bermudez Aceves); Hospital General Reynosa (F. Gonzalez Salazar); Hospital Juan I. Menchaca Hospital Civil de Guadalajara (D. Rodriguez Gonzalez); Hospital Juárez de México (M. PoblanoMorales); Hospital Mèdica Sur (F. Ramirez); Hospital O’Horan (M. Cetina); Hospital 
Privado de Hermosillo (J. Navarro); Hospital Regional $1^{\circ}$ Octubre, Issste (A. Villagomez Ortiz); Hospital San Jose Tec Monterrey (V. Sanchez); Hospital Universitario ‘Dr Jose E. Gonzalez’ (U. Chavarria); IMSS (O. Fernandez-Ponce); Iner (H. Serna Secundino); Instituto de Salud del Estado de Aguascalientes (O. Leonardo); Instituto Mexicano del Seguro Social (R. Diego Manuel, J. Mijangos); Issemym Medical Center (G. Vazquez de Anda); Mexican Red Cross (E. Martin); Ocq Hospital (P. Gutierrez); Secretaria de Salud del Gobierno del Distrito Federal (I. López Islas); Servicios de Salud En Yucatan (L. Soberanes).

Montenegro: Clinical Center of Montenegro (L. Pejakov).

Morocco: Chu Ibn Sina (A. Sbihi); Polyclinique CNSS Derb Ghallef (B. Ouahid); Réanimation Médicale, Hôpital Ibn Sina (M. Naoufel).

Netherlands: Academic Medical Center (A. De Pont); Amphia Hospital (P. Rosseel); Antoni Van Leeuwenhoek Ziekenhuis (J. Ten Cate); Beatrixziekenhuis Rivas Zorggroep (G. Van Berkel); Canisius Wilhelmina Ziekenhuis (S. Corsten); Erasmus Mc University Medical Center (J. Bakker); Hagaziekenhuis (J. Vogelaar); Hofpoort Hospital Woerden (H. Blom); Isala Clinics (H. Kieft); Medical Center Leeuwarden (M. Kuiper); Medisch Spectrum Twente (A. Gille); Radboud University Nijmegen Medical Centre (P. Pickkers); Rode Kruis Ziekenhuis (J. Vet); Slingeland Ziekenhuis (J. Ammann); Spaarneziekenhuis (S. Den Boer); St Antonius Ziekenhuis (R. Wesselink); St Elisabeth Hospital (B. Speelberg); Twenteborg Hospital Almelo (C. Pham); University Hospital Groningen (M. Rodgers); University Hospital Maastricht (D. Bergmans); Vu University Medical Center (J. Groeneveld).

New Zealand: Auckland City Hospital (C. McArthur); Auckland City Hospital (R. Parke); Christchurch (J. Mehrtens); Dunedin Hospital (L. Celi); Hawkes Bay Hospital (R. Freebairn); Middlemore Hospital (N. Rankin); Nelson Marlborough District Health 
Board (C. Heffernan); Palmerston North Hospital (G. McHugh); Starship Children's Hospital (J. Beca); Waikato Hospital (F. Van Haren); Wellington Public Hospital (B. Barry); Whangarei Base Hospital (M. Kalkoff).

Norway: Aker University Hospital (R. Loevstad); St Olavs University Hospital (P. Klepstad); Sykehuset Asker Og Bærum Hf (P. Erno); Sykehuset I, Vestfold Hf, Toensberg (A. Junker).

Pakistan: Armed Forces Institute of Cardiology (S. Naqvi); Jinnah Hospital Lahore (I. Javed).

Panama: Complejo Hospitalario Metropolitano (J. Sinclair).

Peru: Hipolito Unanue Hospital (R. Rivera); Hospital Regional Honorio Delgado (C. Chavez); Hospital Alberto Sabogal Sologuren (Z. Donayre Taber); Hospital Dos De Mayo (R. Quispe Sierra); Hospital Edgardo Rebagliati Martins (J. Muñoz); Hospital Maria Auxiliadora (J. Galvez Ruiz); Hospital Nacional Almanzor Aguinaga Asenjo Essalud Chiclayo (J. Fang Li); Hospital Nacional Arzobispo Loayza (M. Candiotti Herrera); Hospital Víctor Lazarte Echegaray (A. Arroyo); Instituto de Salud del Niño (R. Becerra); Navy Hospital (J. Meza); Peruvian Air Force Central Hospital (M. Mayorga).

Poland: 4th Military Clinical Hospital (P. Garba); Academic Centre for Maritime and Tropical Medicine AMG (J. Kot); Barlicki University Hospital, University of Medical Science, Lodz (T. Gaszynski); Boleslaw Szarecki Teaching Hospital No. 5 of The Medical University in Lodz (M. Piechota); Clinical Hospital No. 2 (S. Renata); Collegium Medicum Jagiellonian University (P. Müller); Institute of Cardiology (J. Stepinska); J. Brudzinski's Hospital in Gdynia (K. Jacek); Jagiellonian University (T. Cieniawa); Karol Marcinkowski University of Medical Sciences (A. Mikstacki, B. Tamowicz); Poznan University of Medical Sciences (A. Bartkowska-Sniatkowska); 
Silesian University of Medicine (E. Karpel); University Hospital Bydgoszcz Cm Umk (K. Kusza); University Hospital No. 2 Poznan (P. Smuszkiewicz); University Hospital Warsaw (M. Mikaszewska-Sokolewicz); Wojewodzki Szpital Specjalistyczny (R. Goraj); Wroclaw Medical University (A. Kubler).

Portugal: Centro Hospitalar Alto Ave (A. Bártolo); Centro Hospitalar Cova Da Beira (M. Castelo-Branco Sousa); Centro Hospitalar Trás os Montes e Alto Douro (F. Esteves); CHLO-Hospital S Francisco Xavier (A. Martins); H S João (T. Oliveira); Hospital CUF Infante Santo (P. Ponce); Hospital Curry Cabral (L. Mourão); Hospital da Luz (C. Febra); Hospital de Egas Moniz (E. Carmo); Hospital de S. José (V. Lopes); Hospital de São Francisco Xavier (P. Póvoa); Hospital de São José (A. Rezende); Hospital Divino Espirito Santo (H. Costa); Hospital do Litoral Alentejano (P. Moreira); Hospital Dr José Maria Grande, Portalegre (F. Pádua); Hospital Fernando Fonseca (A. Leite); Hospital Garcia de Orta (E. Almeida); Hospital Geral de Santo António (M. Alves); Hospital de Pulido Valente (A. Sousa, L. Telo); Hospital de S. João (C. Dias, J. Paiva); Hospital de São Bernardo (R. Ribeiro); Hospital de São Sebastião, EPE (P. Amaro); Hospital Geral de Sto Antánio (A. Carneiro); Hospital de St António dos Capuchos (R. Moreno, R. Matos, S. Afonso); Instituto Português de Oncologia de Lisboa (M. Bouw); Hospital de St Maria (C. França). Qatar: Alkhor Hospital (A. Ibrahim).

Romania: 'Maria Sklodowska Curie' Children's Emergency Hospital, Bucharest (R. Tabacaru); Department Public Hospital (V. Ionita); Fundeni Institute (D. Tulbure); Institute of Cardiovascular Disease (D. Filipescu); Institutul de Boli Cardiovasculare Si Transplant Tg. Mures (S. Pascanu); Spitalul .Sf. Spiridon (I. Grigoras); University Emergency County Hospital (S. Copotoiu). 
Russia: Bakoulev Scientific Center for Cardiovascular Surgery (D. Popov); City Clinical Hospital (E. Lebedev); City Hospital (I. Olga); City Hospital \#7 (A.

Yaroshetskiy); Clinical Hospital №40 (T. Lugovkina); Ekaterinburg University Hospital №40 (B. Dmitry); Izhevsk State Medical Academy (O. Malinin); Moscow Children's Surgery Institut (A. Lekmanov).

Saudi Arabia: Alawi Tunsi Hospital (M. Abulmagd); King Abdulaziz Medical City (Y. Arabi); King Abdulaziz University Hospital (J. Alhashemi); King Fahad Specialist Hospital Dammam (A. Ali); King Faisal Specialist Hospital (K. Maghrabi); Kingdom Hospital (A. Debek); Riyadh Millitary Hospital (M. Malik).

Serbia: Clinical Center Nis (R. Jankovic); Clinical Centre of Serbia (I. Palibrk); Dedinje Cardiovascular Institute (V. Maravic-Stojkovic); KBC Bezanijka Kosa (V. Malenkovic); Military Medical Academy, Belgrade (M. Surbatovic); Unuiversity of Belgrade (V. Bumbasirevic).

Singapore: Changi General Hospital (N. Lim); Kk Hospital (T. Loh); Tan Tock Seng Hospital (H. Tan).

Slovakia: Fakultna Nemocnica Nitra (H. Sekeresova); FNSP Bratislava-Hospital Ruzinov (J. Koutun); Madical Faculty Hospital Kosice (J. Firment); Nusch Bratislava (P. Malik); Reiman Hospital (S. Trenkler).

Slovenia: Clinic Center Ljubljana (I. Muzlovic); General Hospital Novo Mesto (L. Kosec, B. Ozek); General Hospital Slovenj Gradec (D. Kasnik); University Clinic of Respiratory and Allergic Diseases (V. Tomic); University Clinical Center Ljubljana (R. Knafelj); University Medical Center Ljubljana (V. Svigelj).

South Africa: 1 Military Hospital (H. Du Plessis); Groote Schuur Hospital (R. Raine); Johannesburg Hospital (S. Bhagwanjee, G. Richards, J. Scribante); Johannesburg 
Hospital Trauma Unit (J. Goosen); Unitas Hospital (J. De Jager); Wits Donald Gordon Medical Center (G. Schleicher).

Spain: Althaia (O. Rubio); Bellvitge University Hospital (R. Mañez); Centro Medico Delfos (M. Burgueño Campiñez); Clinica Moncloa (M. Alvarez); Clinica Rotger (R. Jorda); Clinica Santa Elena (E. Naveira-Abeigón); Clinica Universitaria de Navarra (P. Monedero); Complejo Hospitalario de Pontevedra (E. Alemparte-Pardavila); Fundacion Hospital Alcorcon (S. Garcia del Valle); Fundacion Jimenez Diaz (C. Perez Calvo); H Vall Hebron (M. Palomar); H.U. Virgen de Las Nieves-H. Traumatología y Rehabilitación (F. Guerrero); Hospital 'Virgen de La Concha'Zamora (A. Caballero Zirena); Hospital Arnau de Vilanova (M. Arribas); Hospital Can Misses (E. Bustamante Munguira); Hospital Casa de Salud (J. Ruiz); Hospital Central de Asturias (A. Blanco Vicente); Hospital Clinic Barcelona (E. Zavala); Hospital Clinic de Barcelona (M. Valencia); Hospital Clinico San Carlos (A. Blesa Malpica); Hospital Clinico San Carlos (F. Martinez-Sagasti, M. Nieto); Hospital Clinico Universitario (G. Aguilar); Hospital Clinico Universitario de Santiago (F. Martinon-Torres); Hospital Comarcal Vinaros (C. Lorente); Hospital de Navarra (J. Insausti); Hospital de Antequera (R. Vegas Pinto); Hospital de Basurto (I. Santos); Hospital de Fuenlabrada (A. Escriba); Hospital de Galdakao (P. Olaechea); Hospital de La Merced (E. Muñoz); Hospital de Manacor (E. Antón Caraballo); Hospital de Mostoles (P. Galdos-Anuncibay); Hospital de Sagunto (V. Lopez Camps); Hospital de Tortosa Verge de La Cinta (F. Esteban-Reboll); Hospital del Sas de Jerez (A. Estella); Hospital Donostia (L. Bocero); Hospital Dr Peset (A. Ibañez); Hospital G. Yagüe (L. Pueyo); Hospital General (L. María Jesús); Hospital General de Asturias (L. Iglesias Fraile); Hospital General de Ciudad Real (J. Silva); Hospital General de Granollers (P. Garro); Hospital General de La Palma (L. Ramos-Gómez); Hospital General de 
L'Hospitalet (A. Rovira); Hospital General de Vic (M. Martin Delgado); Hospital General Salud ‘Obispo Polanco’ (J. Monton Dito); Hospital General Universitario de Albacete (F. Garcia); Hospital General Universitario de Alicante (J. Navarro); Hospital General Universitario de Elche (J. Latour-Perez); Hospital General Universitario de Guadalajara (A. Albaya); Hospital General Universitario Gregorio Marañon (A. Bustinza); Hospital Gran Canaria ‘Dr Negrín’ (J. Sole-Violán); Hospital Marques de Valdecilla (P. Ugarte Peña); Hospital Maz (I. Yuste); Hospital Parque San Antonio (J. De Rojas Román); Hospital Sabadell (J. Vallés); Hospital Sant Joan de Déu (E. Esteban); Hospital Sant Pau (E. Quintana Tort-Martorell); Hospital Santa María del Rosell (M. Moreno); Hospital Santa Maria Madre-Complejo Hospitalario de Ourense (V. López Ciudad); Hospital Santiago Apostol (A. Manzano Ramirez); Hospital Sevilla-Aljarafe (J. Sánchez-Olmedo); Hospital Son Llàtzer (M. Borges); Hospital Terrassa (J. Amador Amerigo); Hospital Torrecardenas (F. Guerrero Gomez); Hospital Universitaio 12 de Octubre (J. Montejo González); Hospital Universitari de Girona Doctor Josep Trueta (J. Sirvent); Hospital Universitari Germans Trias I Pujol (E. Mesalles Sanjuan); Hospital Universitario Arnau de Vilanova (F. Barcenilla-Gaite); Hospital Universitario de Canarias (N. Serrano); Hospital Universitario de Getafe (E. Cerdá); Hospital Universitario de Valme (A. Lesmes Serrano); Hospital Universitario Doce de Octubre (C. Garcia-Fuentes); Hospital Universitario Infanta Crsitina (J. Macias Pingarrón); Hospital Universitario Nasra de Candelaria (E. Espinosa); Hospital Universitario Principe de Asturias (M. Sanchez Garcia); Hospital Universitario Reina Sofía, Murcia (F. Felices); Hospital Universitario Virgen de La Victoria (M. de la Torre-Prados); Hospital Univesitario Puerto Real (H. Maria Jesus); Hospital Valle del Nalon (V. Luis); Hospital Virgen Arrixaca (R. Jara); Hospital Xanit Internacional (M. Briones Lopez); Hospital Xeral Cies (P. Posada); Hu La Paz (B. 
Galvan); Hu La Paz (F. Mariscal); Joan XXIII University Hospital (J. Rello); Morales Meseguer (B. Gil); Puerta del Mar University Hospital (R. Sierra); Rio Hortega University Hospital (J. Rico-Feijoo); San Pedro de Alcantara Hospital (C. Corcobado Márquez); Servicio Navarro de Salud, Hospital Virgen del Camino (J. Izura); Uci H. U. Salamanca (J. González); University Hospital Dr Peset (J. Soto lbáñez).

Sudan: Soba University Hospital (H. Agabani).

Sweden: Anestesikliniken, Södra Älvsborgsläns Sjukhus Borås (P. Petersen); Centralsjukhuset Karlstad (L. Johansson); University Hospital, Linköping (H. Blomqvist, B. Peterzén, N. Wyon); Göteborg (I. Lindström); Kärnsjukhuset Skövde (A. Paulsson); Karolinska University Hospital Huddinge (C. Agvald-Ohman); Karolinska University Hospital, Solna (J. Petersson); Lund University Hospital (H. Friberg); Malmoe University Hospital (V. Einar); OP/IVA Kliniken, Länssjukhuset Ryhov, Jönköping (F. Hammarskjöld); Ostersund Hospital (M. Schindele); Ostra Hospital, Göteborg (S. Arvidsson); Sahlgrenska University Hospital (J. Sellgren); Söder Hospital (Södersjukhuset) (J. Hulting); Södersjukhuset, Stockholm (J. Hulting, J. Häggqvist); Sollefteå Hospital (J. Rudenstam); Sunderby Hospital (D. Lind); The Queen Silvia Children's Hospital (E. Kokinsky); Thoracic Intensive Care, Karolinska University Hospital, Solna (A. Owall); Umeå University Hospital (S. Jacobson); University Hospital, Uppsala (H. Stiernstrom); University Hospital of Örebro (A. Nydahl).

Switzerland: CHUV, Lausanne (P. Eggimann); University of Geneva (R. Stocker); Hirslanden Klinik Beau-Site (G. Loderer); Kantonsspital Liestal (R. Loetscher); Kantonsspital Luzern (A. Mehlig); Lindenhofspital (K. Heer); Neuchâtel (H. Zender); Ospedale Civico Di Lugano (S. Cottini); Regional Hospital Mendrisio (A. Pagnamenta); Stadtspital Triemli (G. Eich); Swiss Paraplegic Center Nottwil (P. 
Felleiter); University Hospital Zurich (M. Marco); University Hospitals of Geneva (J. Pugin).

Taiwan: Changhua Christian Hospital (W. Shu-Hui); Kaohsiung Veterans General Hospital (K. Hsieh).

Thailand: Faculty of Medicine Siriraj Hospital (P. Toomtong); Prince of Songkla University (B. Khwannimit); The Bnh Hospital (P. Kietdumrongwong).

Tunisia: Children's Hospital of Tunis (A. Khaldi); Hopital Aziza Othmana (A. Messadi); Military Hospital of Tunis (I. Labbene); Mongi Slim Hospital (N. Frikha). Turkey: Acibadem Kadikoy Hospital (K. Atalan); Acibadem Bakirkoy Hospital (C. Ates); Acibadem Bursa Hospital (A. Kahveci); Acibadem Kozyatagi Hospital (H. Fistikci); Ankara University (A. Kaya); Ankara University Medical Faculty, Ibni Sina Hospital (E. Ozgencil); Ataturk University Medical Faculty (M. Kizilkaya); Dicle University Medical School (M. Bosnak); Dokuz Eylul University (H. Bodur); Dokuz Eylul University School of Medicine (M. Akan); Erciyes University Medical Faculty (M. Guven); Gazi University School of Medicine (M. Turkoglu); Hacettepe University Hospital (A. Topeli); Inonu University Medical Faculty (T. Togal); Istanbul Faculty of Medicine (N. Uzel); Istanbul Medical Faculty (I. Akinci, N. Cakar, S. Tugrul); Istanbul University Cerrahpasa Medical School (O. Demirkiran); Izmir Ataturk Training and Resarch Hospital (T. Adanir); Memorial Hospital (K. Dogruer); Okmeydani Teaching \& Research Hospital (A. Turkmen); Okmeydani Teaching \& Research Hospital (H. Guven); Ondokuz Mayis University, Medical Faculty (F. Ulger); Selcuk University Meram Faculty of Medicine (S. Kocak).

UK: Aberdeen Royal Infirmary (B. Cuthbertson); Addenbrooke's Hospital (K. Gunning); Barnsley Hospital (Y. Myint); Bristol Royal Infirmary (J. Bewley); Cambridge University Teaching Hospitals (R. Burnstein); Christie Hospital (P. Haji- 
Michael); Dumfries and Galloway Royal Infirmary (D. Wrathall); Kent and Canterbury Hospital (L. Folan); Freeman Hospital (I. Nesbitt); Friarage Hospital, Northallerton (A. Ratnaparkhi); Frimley Park Hospital (S. Pambakian); Glasgow Royal Infirmary (M. Booth); Great Western Hospital Swindon (M. Watters); Guys and St Thomas' NHS Foundation Trust (T. Sherry); Huddersfield Royal Infirmary (U. Buehner); Hurstwood Park Neurosurgical Centre (C. Barrera Groba); James Paget University Hospital (P. Bothma); John Radcliffe Hospital (N. George, J. Frater); Kettering General Hospital (L. Hollos); Lothian University Hospitals Trust (S. McLellan); Macclesfield District General Hospital (J. Hunter); Manchester Royal Infirmary (M. Garrioch, N. O’Keeffe); Medway NHS Trust (N. Divekar); Morriston Hospital (S. Eggert); New Cross Hospital, Wolverhampton (S. Smith); Newcastle General Hospital (A. Vincent); Newham University Hospital Trust (P. Withington); NHS Tayside (C. Macmillan); Northampton General Hospital (R. Webster); Papworth Hospital (A. Vuylsteke); Peterborough Hospitals (B. Appadu); Princess Royal Hospital (C. Barrera Groba); Queen Alexandra Hospital, Portsmouth (P. McQuillan); Queen Elizabeth Hospital (M. Blunt); Queen Elizabeth Medical Center, Birmingham (N. Parekh); Rotherham DGH (D. William); Royal Berkshire Hospital (C. Jones); Royal Blackburn Hospital (A. Krige); Royal Bournemouth NHS Foundation Trust (M. Schuster-Bruce); Royal Cornwall Hospital (J. Boyden); Royal Devon \& Exeter NHS Foundation Trust (C. Boulanger); Royal Infirmary of Edinburgh (D. Swann); Royal Liverpool University Hospital (J. Walker); Royal Marsden Hospital (T. Wigmore); Royal Shrewsbury Hospital (R. Law); Royal Sussex County Hospital (F. Baldwin); South Tyneside Hospital (C. Muench); Southmead Hospital (S. Robinson); St George's Hospital (A. Crerar-Gilbert, A. Rhodes); St Helens and Knowsley Hospital (T. Mahambrey); St John's Hospital (L. Cameron); St James's University Hospital (J. Thornton); St Mary's Hospital (M. 
Stotz); St Peters Hospital (M. Russell); Stirling Royal Infirmary (A. Longmate);

Tameside General Hospital (R. Kitson); Taunton \& Somerset NHS Trust (B. Browne);

The Hillingdon Hospital (A. Thorniley); The James Cook University Hospital (I.

Gonzalez); Torbay Hospital (M. Swart); University College Hospital (M. Singer);

University Hospital Birmingham (N. Gautam); University Hospital of South

Manchester (V. Prasad); University Hospitals Coventry \& Warwickshire NHS Trust

(D. Watson); West Middlesex University Hospital (T. Szakmany); West Suffolk

Hospital (J. Cardy); Western Infirmary Glasgow (A. Binning); Wexham Park Hospital

(R. Loveland); Wirral University Teaching Hospital (J. Gannon); Wolverhampton

Hospital (G. Martinelli); Wythenshawe Hospital (P. Nightingale); Yeovil District

Hospital (J. Howes).

Ukraine: Lugansk City Hospital No. 7 (Y. Nalapko); Lugansk District Hospital (Y. Nalapko) .

United Arab Emirates: Al-Mafraq Hospital (S. Rady); Department of Health \& Medical Services (A. Alsabbah); Dohms (N. Elahi); Dubai Hospital (H. Al Rahma); Tawam Hospital (M. Rahman, S. Kashef).

Uruguay: Amecom (H. Escanda); Comta (J. Baraibar); Hopital Policial (D. Paciel); Hospital Maciel (H. Bagnulo); Hospital Tacuarembo (F. Hitta); Médica Uruguaya Corporación de Asistencia Médica (P. Nadales); Sanatorio Americano-FEMI (H. Albornoz).

USA: Baystate Medical Center (J. Steingrub); Denver Health Medical Center (L. Ammons); Emory University Hospital-MICU (M. Fisher); Englewood Hospital Medical Center (N. Gandhi); Grady Memorial Hospital-Emory University (G. Martin); Hospital of The University of Pennsylvania (C. Deutschman); LDS Hospital, Salt Lake City (N. Dean); Inova Fairfax Hospital (C. Michetti); Los Angeles County + University of 
Southern California Medical Center (H. Belzberg); LSUHSC Shreveport (K. Hutchinson); Maine Medical Center (T. Van der Kloot); Mayo Clinic (B. Afessa);

Mount Sinai School of Medicine (D. Kaufman); Nassau University Medical Center (J. lqbal); New York University (D. Ost); Northwestern University (S. Afifi, M. West, R. Wunderink); Olive View UCLA Medical Center (S. Stein); Oregon Health \& Science University (D. Hagg); Orlando Regional Medical Center (E. Jimenez); Penn State Hershey Medical Center (S. Blosser); Rochester General Hospital (S. Chhangani); Rush University Medical Center (R. Kleinpell); Rutland Regional Medical Center (H. Reich); Scott and White Hospital (E. Fields); Sharp Memorial Hospital (D. Willms); South Texas Veterans Health Care System (P. Castellanos-Mateus); St Joseph Medical Center FHS (L. Melnik); Texas Tech University Health Sciences Center (L. Oud); Cardiovascular ICU, The Methodist Hospital, Houston (E. Chi, Y. Brown); Medical ICU, The Methodist Hospital, Houston (R. Halfon); The University of Mississippi Medical Center (A. Badr); The University of Texas Health Science Center at San Antonio (M. Restrepo, P. Castellanos-Mateus); University of Chicago (A. Pohlman); University of Cincinnati (R. Branson); University of Kansas Hospital (S. Simpson); University of Miami School of Medicine (D. Kett); University of Michigan (T. Jacobs, P. Park, W. Wahl); University of Texas Health Science Center at San Antonio (C. Patricia); University of Toledo Medical Center (J. Hammersley, T. Papadimos); University of Virginia (R. Sawyer); UTHSC at Memphis-Regional Medical Center (Site) (A. Freire); Veterans Caribbean Healthcare System (W. Rodriguez); Washington Hospital Center (A. Ryan); West Suburban Medical Center (B. Margolis); Winthrop University Hospital (M. Groth).

Venezuela: Hospital Dr Luis Ortega (Z. Salmen); Hospital Unversitario de Caracas (C. Pacheco). 
Vietnam: Bach Mai Hospital (T. Bui); Franco Vietnamese Hospital (F. Potie); Ninh Thuan Hospital (C. Nguyen Huu). 